\title{
International projects and political risk management by multinational enterprises: insights from multiple emerging markets
}

\author{
Tahir Ali
}

School of Marketing and Communication, University of Vaasa, Vaasa, Finland

Aurangzeab Butt

School of Technology and Innovations, University of Vaasa, Vaasa, Finland

Ahmad Arslan

Department of Marketing, Management and International Business,

University of Oulu, Oulu, Finland

Shlomo Yedidia Tarba

Strategy and International Business, University of Birmingham, Birmingham, UK

Sniazhana Ana Sniazhko

School of Management, University of Vaasa, Vaasa, Finland, and

Minnie Kontkanen

School of Marketing and Communication, University of Vaasa, Vaasa, Finland

\begin{abstract}
Purpose-This study investigates an under-researched yet fundamental question of how a developed country multinational enterprises (DMNE) perceives and manages political risks when undertaking infrastructure projects in the emerging markets (EMs).

Design/methodology/approach - The authors use an abduction-based qualitative research approach to analyze six international project operations of a multinational enterprise originating from Finland in five EMs. Findings - The findings suggest that the overall nature of political risks in EMs is not the same, except few political risk factors that are visible in most EMs. Consequently, the applied risk management mechanisms vary between EMs, except with few common mechanisms. The authors develop an integrative analytical framework of political risk management based on the findings.

Originality/value - This paper is one of the first studies to identify political risk factors for western MNEs while undertaking international project operations and link them to reduction mechanisms used by them. The authors go beyond the notion of risk being conceptualized at a general level and evaluate 20 specific political risk factors referred to in extant literature. The authors further link these political risk factors with both social exchange and transaction cost theories conceptually as well as empirically. Finally, the authors develop a relatively comprehensive analytical framework of political risk management based on the case projects' findings that combine several strands of literature, including the social exchange theory, transaction cost theory, international market entry, project management and finance literature streams.
\end{abstract}

Keywords Emerging markets, International projects, Market entry, Political risk, Risk management mechanisms

Paper type Research paper

(C) Tahir Ali, Aurangzeab Butt, Ahmad Arslan, Shlomo Yedidia Tarba, Sniazhana Ana Sniazhko and Minnie Kontkanen. Published by Emerald Publishing Limited. This article is published under the Creative Commons Attribution (CC BY 4.0) licence. Anyone may reproduce, distribute, translate and create derivative works of this article (for both commercial and non-commercial purposes), subject to full attribution to the original publication and authors. The full terms of this licence may be seen at http:// creativecommons.org/licences/by/4.0/legalcode
Political risk

management

Received 29 March 2020

Revised 5 December 2020

5 February 2021

22 May 2021

11 July 2021

Accepted 19 July 2021 
IMR

38,6

1114

\section{Introduction}

Emerging markets (EMs) are major drivers of global economic growth (Gilpin, 2018). Market liberalization, along with a higher economic growth rate, growing middle-income class and cheap and skilled labor in EMs, has brought immense opportunities for developed country multinational enterprises (DMNEs). The increasing need for improved infrastructure predetermines economic growth in EMs (e.g. Cavusgil et al., 2013). According to McKinsey and Company (2017), an investment of US $\$ 3.7$ tn (i.e. $4.1 \%$ of the world gross domestic product (GDP)) is required in economic infrastructure annually until 2035 , and $63 \%$ of this investment is needed in EMs. Further, Oxford Economics (2017) reports that two-thirds of infrastructure investment in EMs will be required for logistics (road, rails, etc.) and power sector developments. These expanding investments in the infrastructure development in EMs, especially in logistics and power sectors, are attracting DMNEs to take infrastructure projects in EMs (Kardes et al., 2013).

As recently highlighted by Donthu et al. (2021) in their bibliometric review of International Marketing Review (IMR), global business environment and the EMs in particular have emerged among the evolving thematic and intellectual structures that are driving IMR's academic influence and impact. Moreover, firms facing the EM turbulence have to develop network-based capabilities to maintain the competitive advantages (Ngasri and Freeman, 2018) and nurture the strategic agility (Nyamrunda and Freeman, 2021). In addition, investigation of the foreign market entry modes is one of the integral parts of the international marketing domain (Oliveira et al., 2018; Samiee and Chirapanda, 2019; Vissak et al., 2020; Watson IV et al., 2018).

While EMs represent many opportunities; there are risks to consider. DMNE operations in EMs might be disrupted by corruption, political risks, economic crises, logistics issues or bureaucracy, to mention a few (Henisz and Zelner, 2010). Risks related to host countries' political environment are a major concern of DMNEs in their entry mode choices (e.g. Kraus et al., 2015). The political risks and constraints that DMNEs face in EMs are different from those in mature markets (Hiatt and Sine, 2014). Moreover, the unpredictability and complexity of those political risks vary among EMs. Furthermore, EMs are replete with institutional voids, meaning that they lack institutes that can help DMNEs identifying these risks and facilitating market transactions (Khanna and Palepu, 2010). Without the benefit of specialized intermediaries in EMs that analyze market information and facilitate transactions, risk management for DMNEs becomes even more difficult (Khanna and Rivkin, 2001). Although the existing literature offers several frameworks on risks and their management mechanisms, these frameworks remain largely conceptual in their original form (e.g. Buckley, 2000; Miller, 1992; Simangunsong et al., 2012). Furthermore, frameworks from developed market settings are not necessarily relevant for EMs contexts that are characterized by a higher complexity (Gao et al., 2017; Marquis and Raynard, 2015). In this view, there are clear opportunities in expanding our understanding of DMNEs perception and risk management mechanisms in EMs. This study builds on this opportunity.

Despite political risks and risks associated with international market entry modes, DMNEs bring projects into EMs as a source of additional profit generation (Lessard, 1996; Jiang et al., 2019). International project operations (IPOs) are an important market entry mode that is commonly utilized in heavy industries (Owusu et al., 2007; Welch et al., 2018). DMNE's ability to properly execute IPOs has valuable implications for its operation that can be revealed in financial gains, growth potential, market expansion and good reputation (Low et al., 2013). Nevertheless, large investments, high level of responsibility and tight deadlines that are associated with IPOs, make the influence of the host country's political risk on MNEs even more intense (e.g. Chang et al., 2018; Owusu et al., 2007; Steffen and Papakonstantinou, 2015). In particular, DMNEs that enter an EM through IPOs are likely to face such political 
risks as currency transfer restrictions, breach of contract, expropriation, regulatory and bureaucratic risks, and non-governmental action risks (Sachs, 2006).

Subsequently, DMNEs deploy additional mechanisms to safeguard their project business operations from political risk factors in EMs (Steffen and Papakonstantinou, 2015). Although identifying political risks before undertaking infrastructure projects is integral to managing those risks and existing international market entry research has offered certain insights on the nature of political risk in various host countries (e.g. Deng et al., 2018; Han et al., 2018; Huemer, 2004; Khattab et al., 2007), empirical work specifically dealing with the political risk management in IPOs is very limited (Chang et al., 2018; Mullner, 2016). In a recent study on IPOs, Dandage et al. (2018) ranked the risk factors and identified that political risk is the biggest risk in IPOs. However, they acknowledged the limited guidance on managing such risks. Similarly, Kardes et al. (2013), as well as Mullner (2016), also call for more research on political risk management in IPOs. Thus, we aim to fill this gap in extant international market entry literature by explicitly examining the question as to how a DMNE perceives and manages political risks when undertaking infrastructure projects in EMs.

To enhance our understanding of DMNE's political risk management while executing IPOs in EMs, this study integrates relevant insights from the social exchange theory (SET), transaction cost theory (TCT), international marketing, market entry mode and project management (PM) literature streams. Existing literature offers several perspectives with regard to political risk management. First, several studies (Cavusgil et al., 2013; Luo, 2001, 2004) built on the SET suggest the alignment of MNE's objectives with the host government's social and economic objectives, and developing trust-based informal networks with local business and people of the host government to reduce political risk. Another strand of research (Forlani et al., 2008; Lopez-Duarte and Vidal-Suarez, 2010; Mullner, 2016; Puck et al., 2009), built on the TCT, suggests the formation of equity joint ventures (EJVs), contractual joint ventures (CJVs) or an arm's length classical contract with the host country firms to reduce political risk. In contrast to the market entry literature, finance literature (Lessard, 1996; Voelker et al., 2008) suggests for buying political risk insurance (PRI), and PM literature (Turner, 2001) suggests for the choice of appropriate payment method (i.e. the choice between fixed cost, cost plus fixed fee and target price) in IPOs for reducing political risks. Given the intricate nature of political risks in EMs, we believe that various strands of prior literature should be integrated to better understand the management of political risks in IPOs.

Research on international market entry decisions has focused on the relationship between institutes and DMNE outcomes, emphasizing that DMNE operation depends on and varies across different institutional environments (Ahuja and Yayavaram, 2011; Douglas and Craig, 2011; Hiatt and Sine, 2014). However, a certain group of scholars argue that institutions are more than just an environment because they directly influence DMNEs' choice of actions (Ingram and Silverman, 2002). Hence, DMNEs can achieve a competitive advantage through entry modes that overcome and capitalize on the EMs' institutional environments (Henisz, 2000). Although, existing literature has established a shared understanding of the entry mode choices such as acquisitions, greenfield investments, joint ventures and franchising, and their associated dynamics (e.g. Chiao et al., 2010; Erramilli and Rao, 1993), the research focus on IPOs as an entry mode choice is rather scarce. Notwithstanding the compelling research on recognized entry modes, understanding unique and nuanced aspects of less researched entry mode choices will expand our knowledge about underlying processes of DMNEs' decisionmaking and their international operations (Hennart and Slangen, 2015). To understand the underlying mechanisms that allow DMNEs to enter an EM through IPOs and to facilitate their long-term survival, this study explores the process through which DMNE managers perceive and address different kinds of political risks in EMs.

We adopt an abduction-based qualitative case study research approach to explore the perceived political risks and their management by a European MNE having infrastructure
Political risk management

1115 
IMR

38,6

1116

development IPOs in five EMs of Bangladesh, Indonesia, Brazil, Jordan and Pakistan. While much has been reported about the political obstacles faced by EM MNEs undertaking IPOs in developing countries (Chang et al., 2018; Jiang et al., 2019; Zhang and Wei, 2012), political risk perception and its management by DMNEs undertaking infrastructure projects in EMs is rarely investigated.

This study makes several contributions to the literature on political risk in international entry mode literature. First, the study identifies 20 political risk factors that DMNEs in focus evaluate while planning to enter an EM. Furthermore, the study found that political risks in five EMs are perceived differently by the managers from one DMNE. Managers who work on the same project and operate in EMs together still perceive political risks differently. Acknowledgment of different managerial perceptions is important to consider while deciding to enter EMs because these markets are characterized by higher complexity than developed markets, and they lack intermediary institute that could identify risks for the managers in DMNEs (Gao et al., 2017).

Second, by focusing on IPOs as a specific market entry mode, we found that political risks are subject to constraints from several mechanisms, where some mechanisms are used in all EMs to mitigate political risks, and some are used only in a few EMs to mitigate the political risks. Specifically, this study reveals that managers use both control and flexibility mechanisms to manage political risks in EMs. Two flexibility mechanisms from the SET, namely, "aligning objectives with host government" and "developing trust-based informal networks with local business and people of host government," and one control mechanism from finance literature, namely, "obtaining payment guarantee from local or global financial and commercial institutes," and two control mechanisms from the PM literature, namely, "fixed-term payment method" and "progressive payments," are commonly used by a DMNE to mitigate political risks in EMs. Especially, the two mechanisms of "obtaining payment guarantee from local or global financial and commercial institutes" and "progressive payments" are new findings that prior studies have not addressed. Detailed illustration of political risk management mechanisms is an important finding because existing literature emphasizes the dominance of the control mechanisms to minimize political risks. Emerging findings, however, challenge the effectiveness of a control mechanism in risk management and question whether the control can actually be sustained (Streatfield, 2001). Hence, this paper empirically illustrates that managers in DMNEs rely on both control and flexibility to manage political risks in EMs.

Third, we develop an overarching, comprehensive and holistic analytical framework on political risk management based on the empirical findings of the case projects that combine several strands of literature; SET and TCT from international market entry, PM literature and finance literature (Figure 4). Considering that existing frameworks on risks have been largely conceptual and designed primarily for the developed markets, this framework contributes to the literature by extending our understanding of political risks and mechanisms to manage these risks in EMs. This upgraded analytical framework also sets a ground for future empirical research.

Lastly, we find that managers in DMNEs identify political risks and decide on the mechanisms to reduce them during the second stage of the project life cycle (Figure 3). We assume that such a nuance adds to our understanding of how managers in DMNE made decisions related to the capitalization of the environment in which they operate.

\section{Theoretical standpoint}

\subsection{Political risk}

Based on Knight's (1921) seminal conceptualization, risk refers to a set of possible outcomes, and the likelihood of each occurring can be calculated, while uncertainty refers to outcomes 
where the likelihood of each taking place is unknown. Therefore, unlike uncertainty, which is unmeasurable, random and unpredictable, the risk is, to some degree, measurable (Mullner, 2016). Yet, this approach has been challenged due to its failure to capture decision-makers' role (Hsieh et al., 2010). From the decision-makers' point of view, the risk is often perceived as associated with hazards, disappointing or negative outcomes (Deligonul, 2020; Miller and Leiblein, 1996), which significantly impacts the organization's value and its ability to achieve targets. Therefore, risk is defined here as the managerial perception of potential instabilities and vulnerabilities faced by MNEs that impose limitations, restrictions or even losses in international markets (Ahmed et al., 2002).

In the international market entry context, Meschi (2005) highlights that risk involves political and economic risks. Although the importance of economic risk in MNE's international operations is recognized in prior literature (e.g. Ahmed et al., 2002; Deligonul, 2020; Puck et al., 2009), the main interest of the current study lies in political risk. Broadly speaking, political risks emanate from the possibility of adverse effects on MNE's business due to the host country's potential events. Khattab et al. (2007) noted that prior literature concerned with political risk conceptualization is divided into two groups. One group of researchers define political risk as risk arising from political actions of the government, which include taxation restrictions, currency inconvertibility, contract repudiation, import and/or export restrictions, ownership and/or personnel restrictions, expropriation and/or confiscation (e.g. Butler and Joaquin, 1998; Deligonul, 2020). On the contrary, other groups of researchers define political risks as risks arising from governmental and societal actions, and social actions include demonstrations, riots and insurrection, revolutions, coup d'etat, civil wars and terrorism (Stosberg, 2005).

Considering that EMs have an under-developed social-political environment that can harm MNEs' operations (Casson and Lopes, 2013), managerial perception of political risk would depend on various political and societal events in the host country. Subsequently, political risk in EMs stems from potential political and social events that may cause adverse effects on an MNE's business in EMs. Factors such as political violence, regime changes, coups, revolutions, breaches of contract, terrorist attacks, wars and discriminatory actions of the host government (e.g. expropriation, unfair compensation, foreign exchange restrictions, unlawful interference, capital restrictions, corruption and labor restrictions) are among the types of political risk possibilities, especially in IPOs (Chang et al., 2018). Prior research suggests that political risk causes extra expenditures or unexpected adjustments to the project plan, direct financial losses, less overall satisfaction and hence negatively affects the continuity of an MNE's IPOs in the target country (Chang et al., 2018; Zhang and Wei, 2012). Therefore, political risk in IPOs should be handled effectively to materialize the benefits of the project (Chang et al., 2018).

\subsection{International project operations and political risk identification}

Historically, a project is a one-time "temporary endeavor undertaken to create a unique product or service" (PMI, 2000, p. 4). However, project-based business operations have been on the rise since the origination of modern PM in the 1960s (Turner, 2009). IPOs cover "a broad mix of activities involved in the design and construction of different plants and facilities: such as housing, office buildings, factories, industrial plants, mining development, defense establishments, and social infrastructure facilities (power utilities, transport, etc.)" (Luostarinen and Welch, 1990, p. 126). Kardes et al. (2013) report that the lack of appropriate infrastructure in EMs has increased the demand for large-scale projects, especially during the past two decades. Consequently, many DMNEs, which originally started operations as original equipment manufacturers (OEMs) of world-renowned products, have also undertaken IPOs as their growth strategy (Owusu et al., 2007; Kowalkowski et al., 2015). Among such DMNEs, Siemens, ABB, Mitsubishi, Areva, Caterpillar and General Electrical
Political risk management 
IMR 38,6

\section{8}

are a few prominent examples. These OEMs have undertaken highly complex mega projects (e.g. Kardes et al., 2013) and made a considerable contribution to the world's infrastructure development. This study focuses on one such MNE, which originally started as OEM, but later also started undertaking IPOs in the energy sector.

Prior research suggests that instead of viewing IPOs as a single step, it is useful to view them as a process (Welch et al., 2018). Cova and Holstius (1993) present six stages of the project process: search, preparation, bidding, negotiation, implementation and transition. Though the scholars mention that there may be variations on how the process proceeds in an individual project case, we have attempted in Table 1 to provide an overview of the stages of the project process found from the secondary sources of our case IPOs. The project process is a cycle of four stages of market development and opportunity search, project preparation and development, bidding and negotiation, and implementation. Key activities performed during each stage are also elaborated in Table 1.

The seminal work of Liesch et al. (2011) suggests that decision-makers initially face uncertainty only. As decision-makers actively gain more information, they convert some uncertainties to risk, allowing them to make decisions and take actions. This evolving view is a key step that can help to bridge the existing research on risk and uncertainty in IPOs (Mullner, 2016). Therefore, the availability of information reduces uncertainty from the decision-maker's point of view and converts it into a risk. Project literature widely acknowledges that uncertainty is highest at the initial stage of the project and diminishes and converts into risk as the project progresses due to information accumulation (Samset and Volden, 2016).

\subsection{Mechanisms of political risk management}

Risk management is a structured process to minimize or mitigate the likelihood of risks and their negative effects (Deligonul, 2020; Mabrouki et al., 2014). International Organization for Standardization (ISO, 2018) has identified four steps to manage business risk: identifying the potential risks, analyzing and evaluating them, choosing and implementing actions to reduce them, and monitoring the risks. Although process identifies the steps to manage and monitor the business risks, it does not specify mechanisms for managing business risks, including the political risks. Therefore, we carried out extensive literature review on the political risk management and found no precise theoretical model for managing political risk in IPOs.

\begin{tabular}{lll}
\hline Phases & Segment & Main activities \\
\hline Stage 1 & $\begin{array}{l}\text { Market development and } \\
\text { opportunity search }\end{array}$ & $\begin{array}{l}\text { Scanning the targeted markets and identifying project } \\
\text { opportunities, creating market demand on the basis of products } \\
\text { and services the MNE offers, evaluating the resource need for } \\
\text { doing profitable business in a particular market }\end{array}$ \\
Stage 2 & $\begin{array}{l}\text { Project preparation and } \\
\text { development }\end{array}$ & $\begin{array}{l}\text { Developing opportunities through influencing and conjunction } \\
\text { with key players in the market, getting information and } \\
\text { participating in preparing tender specifications }\end{array}$ \\
Stage 3 & Bidding and negotiation & $\begin{array}{l}\text { Setting up a proposal and agreeing on the business terms in the } \\
\text { form of formal contracts, assembling specifications for preparing } \\
\text { tender-specific solutions to be delivered }\end{array}$ \\
& $\begin{array}{l}\text { Execution, supervision, delivery and testing of the delivered } \\
\text { solution; evaluation of delivery process and stakeholder } \\
\text { relationships for future project business as the success of one } \\
\text { project leads to multiple similar opportunities in the same } \\
\text { country }\end{array}$ &
\end{tabular}

Table 1.

Project business

phases (modified from Cova and

Holstius, 1993)
Scanning the targeted markets and identifying project and services the MNE offers, evaluating the resource need for doing profitable business in a particular market with key players in the market, getting information and participating in preparing tender specifications form of formal contracts, assembling specifications for preparing tender-specific solutions to be delivered relationships for future project business as the success of one country 
However, this review led us to identify three streams of literature, which can be employed to explain the mechanisms for managing political risk in IPOs: international market entry, finance and PM literatures.

In the international market entry literature, scholars have used the SET and TCT to manage the political risks. The SET is a sociological theory initially developed to analyze people's social behavior in terms of the exchange of resources (Blau, 1964). Although the origins of the SET are at the individual level, the theory has been extended to inter-firm level (e.g. Muthusamy et al., 2007; Ali and Larimo, 2016) and MNE-host government level (e.g. Luo, 2001, 2004). As described here, the logic of theory "that no actor is self-sufficient, actors will have to interface with each other to obtain needed complementary resources" has been extended to the MNE-host government level. According to the SET, MNEs and host governments need each other for critical complementary resources in today's world economy, and sharing complementary resources cooperatively creates a payoff for both (Luo, 2001, p. 402). Hence, the SET assumes a cooperative relationship between MNEs and host country governments by underscoring the potential for mutual gain (Luo, 2001, 2004). The research built on this assumption has proposed flexibility-cooperative mechanisms, such as the alignment of an MNE's objectives with the host government's social and economic objectives and developing trust-based informal networks with local businesses and people of the host government to reduce political risk (Cavusgil et al., 2013). However, the TCT assumes a conflictual-adversarial relationship between the foreign MNEs and the host government due to their different objectives and self-interest with guile (Luo, 2001, p. 402). The former focuses on wealth generation, while the latter focuses on social welfare (e.g. Luo, 2001, 2004). The research built on this assumption has proposed for control mechanisms, such as the formation of EJVs with a target country firm (Lopez-Duarte and Vidal-Suarez, 2010; Puck et al., 2009). This assumption is built on the logic that the target country firm's possession of country-specific knowledge and overall sharing of resources and risk in an EJV should reduce political risks. However, another group of TCT scholars argues that an EJV with a target country firm can expose an MNE to particular risks associated with partners' behavior (Ahmed et al., 2002). Therefore, instead of EJV formation, MNEs should negotiate an arm's length classical contract or a CJV with a target country firm to manage the political risks (Mullner, 2016). Differentiating from the international market entry literature, finance literature suggests buying PRI as another control mechanism to reduce political risk (e.g. Lessard, 1996; Voelker et al., 2008). Finally, the PM literature proposes that the choice of appropriate payment method (i.e. the choice between fixed cost, cost plus fixed fee and target price) in IPOs is an important control mechanism that mitigates the political risks. Furthermore, conventional wisdom from the PM literature suggests that at high political risk, cost plus fixed fee and target price are the best methods to manage these risks (Turner, 2001). Thus, various strands of prior literature propose a range of mechanisms to reduce political risk in IPOs ranging from different strategic options to payment methods. Given the complex and multifaceted nature of political risks in EMs, we adopt the view that several mechanisms are required to reduce them. We develop the following comprehensive conceptual framework of political risk management based on the prior literature as well as the first phase of data collection and analysis (Figure 1). After the second phase of data collection and analysis, this framework has been further upgraded (Figure 4).

\section{Research methodology}

This study adopts an abduction-based qualitative research approach as we are taking an exploratory stance and are interested in offering a richer understanding of the DMNEs' perception and management of political risks when undertaking infrastructure projects in EMs. An abduction-based qualitative research approach is particularly effective in opening the "black box" to bring forth a contemporary phenomenon within its real-life context,
Political risk management

1119 
IMR

38,6

Figure 1.

Proposed conceptual framework of political risk management

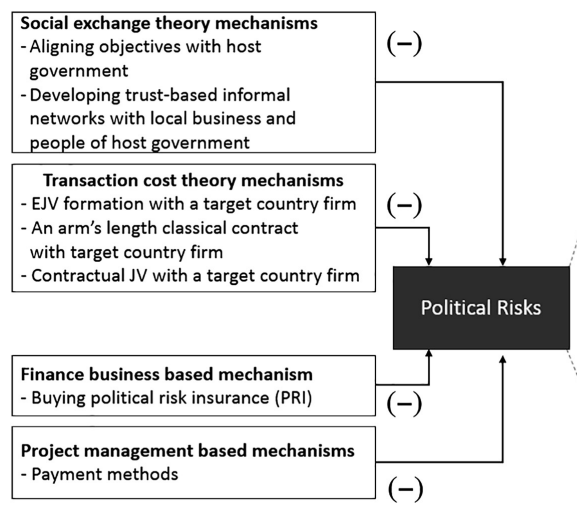

Political Risk Factors

1- Corruption and bribe

2- Delay in approval of permits

3- Nationalism or confiscation

4- Profit remittance and exchange restrictions

5-Import restrictions

6- Discriminatory taxation/change in tax regulations

7- Political regime change

8- Restriction on number of expatriate employee

9- Contract repudiation

10- Excessive demands and variations in project from host

Gov. over time (contract violations)

11- Enforced renegotiations of contract by host government

12- Unstable government policies impacting the project

13- Unstable local transportation rules and regulation

14- Terrorism at site location

15- Risk of labor unions/labor protests

16- Outbreak of inter-state war

17- Social violence/strikes

18- Weakly enforced laws and regulations

19-Anti-project demonstrations by public

20-Security problems/risk of violent attack on project site

especially when limited guidance is available in the literature (Teagarden et al., 2018; Yin, 2003). In particular, simultaneous use of available literature and qualitative data from the case company enabled us to understand better the neglected aspects of political risk perception and its management by DMNEs, thus helping us draw new insights. We selected six case projects of a single MNE that has decades of experience of IPOs in EMs. Each of the case projects was a unique platform (e.g. Huemer, 2004; Owusu et al., 2007) and tool (e.g. Dubois and Gadde, 2002) to investigate the real-world phenomenon of managing political risk in IPOs, from opportunity search stage till the project completion stage (e.g. Cova and Holstius, 1993). Key informants helped us select the case projects, referred to as "key informant sampling" by Fletcher and Plakoyiannaki (2011). However, following Yin (2003), multi-criteria were used to select the case projects referred by the key informants. First, the case projects had to be in EMs as our study focused on analyzing the perception and management of political risks in EMs. Second, the case projects had to be completed so that we should be able to explore the issues related to the political risk management mechanisms that the MNE employed. Third, the case projects had to be in the energy sector so that industry differences are constrained.

\subsection{Data collection and analysis}

This research seeks an abductive approach to data collection and analysis by systematically combining the theory and empirical data from research cases (Dubois and Gadde, 2002). Accordingly, we did not follow a linear approach wherein a literature review-based model could lead to data collection and analysis. Rather, we adopted an inductive-deductive approach of several updates to the model, which was eventually used for thematic data analysis and the case findings presentation. In particular, we adopted a two-phased approach of data collection and analysis (Table 2).

The first phase comprises the development of the research model and data collection simultaneously, where we exchanged emails with key informants and later undertook face-toface meetings (Yin, 2003). The logic of doing project business, sources of political risks and their used strategies for managing those risks in the project business context were learned from the key informants. Meanwhile, researchers collected secondary data from the World Wide Web about the case company and its project operations modes. Key informants also facilitated face-to-face discussions with some of the case projects' team members and helped access some of the case project-specific information (secondary data) for this research (Table 2). This first phase of collecting primary and secondary data enabled combining the 


\begin{tabular}{|c|c|c|c|c|}
\hline Phases & Data sources & Category & Timing & Political ris \\
\hline \multirow[t]{6}{*}{ Phase 1} & $\begin{array}{l}\text { World Wide Web of the case company and } \\
\text { business performance reports }\end{array}$ & Secondary & $\begin{array}{l}\text { In parallel with the } \\
\text { literature search }\end{array}$ & \\
\hline & $\begin{array}{l}\text { Case company general guidelines on the business } \\
\text { ethics, strategy and future vision (limited access to } \\
\text { the material shareable with the externals) }\end{array}$ & Secondary & $\begin{array}{l}\text { In parallel with } \\
\text { literature search }\end{array}$ & \\
\hline & Informal discussions with the case project team & Primary & In parallel with the & 1121 \\
\hline & $\begin{array}{l}\text { members and the key informants (total eight } \\
\text { discussions) }\end{array}$ & & literature search & \\
\hline & $\begin{array}{l}\text { Case project data (external stakeholder reports, } \\
\text { project performance reports and key milestone }\end{array}$ & Secondary & $\begin{array}{l}\text { In parallel with } \\
\text { literature search }\end{array}$ & \multirow{3}{*}{$\begin{array}{r}\text { Table } 2 . \\
\text { Two-phase approach } \\
\text { of data collection and } \\
\text { analysis }\end{array}$} \\
\hline & & & & \\
\hline Phase 2 & $\begin{array}{l}\text { Targeted interviews with semi-structured } \\
\text { approach }\end{array}$ & Primary & $\begin{array}{l}\text { After the theoretical } \\
\text { model }\end{array}$ & \\
\hline
\end{tabular}

theory with the empirical world (Dubois and Gadde, 2002) and developing the preliminary research framework (Figure 1).

The second phase of data collection and analysis constituted of 14 semi-structured interviews of key experts identified during the first phase of data collection. Additionally, their significant role in the decision-making related to the case projects and at the case company's management level was verified with the key informants. The interviewees were contacted via emails with the reference of key informants. Before the interview, an interview guide (protocol) was sent to each interviewee. Alongside, the researchers verified their consent to participate in this research and guaranteed case data security and anonymity of the interviewees and the case projects.

While conducting interviews, we used the earlier shared interview guide (protocol) and a list of typical questions to structure our discussion around the research question. Each respondent was asked about (1) the physical structure of the project in target EM and whether the respondent experienced the project as a single step or comprising of different steps/stages and what were those stages, (2) their experience about the importance of political risks in IPOs in the target EM, (3) at what stage of the project, the political risks were assessed and what political risk factors were observed in the target EM, (4) what stage of the project, strategies/mechanisms were chosen to manage those political risks and (5) what strategies/mechanisms their firm had employed for managing political risks and their effectiveness in reducing political risks. Respondents were also asked about the criteria, if any, their firm had used to measure the project performance and their level of satisfaction with the project performance. For further clarification of their responses, some interviewees also shared some of the project performance reports and key milestones of the case projects (secondary data). An overview of interviewees' positions, their involvement in project stages, their experience in project operations and each interview's duration and the medium is presented in Table 3.

Based on the interviews, informal discussions and case project data, the case project briefs were developed, similar to the narrative strategy (Richmond, 2002; Riessman, 2005). Herein, the purpose was not to establish causality between the perception of political risks and the management of political risks in IPOs but to explore the mechanisms which Energy Co. deployed to manage the political risks. Therefore, instead of fracturing data into codes, the researchers connected (Maxwell, 2013, p. 112) the case briefs with the literature identified themes (i.e. political risk factors and the mechanisms of political risk mitigation). This was done manually on paper for each of the cases by two researchers individually, and then the 


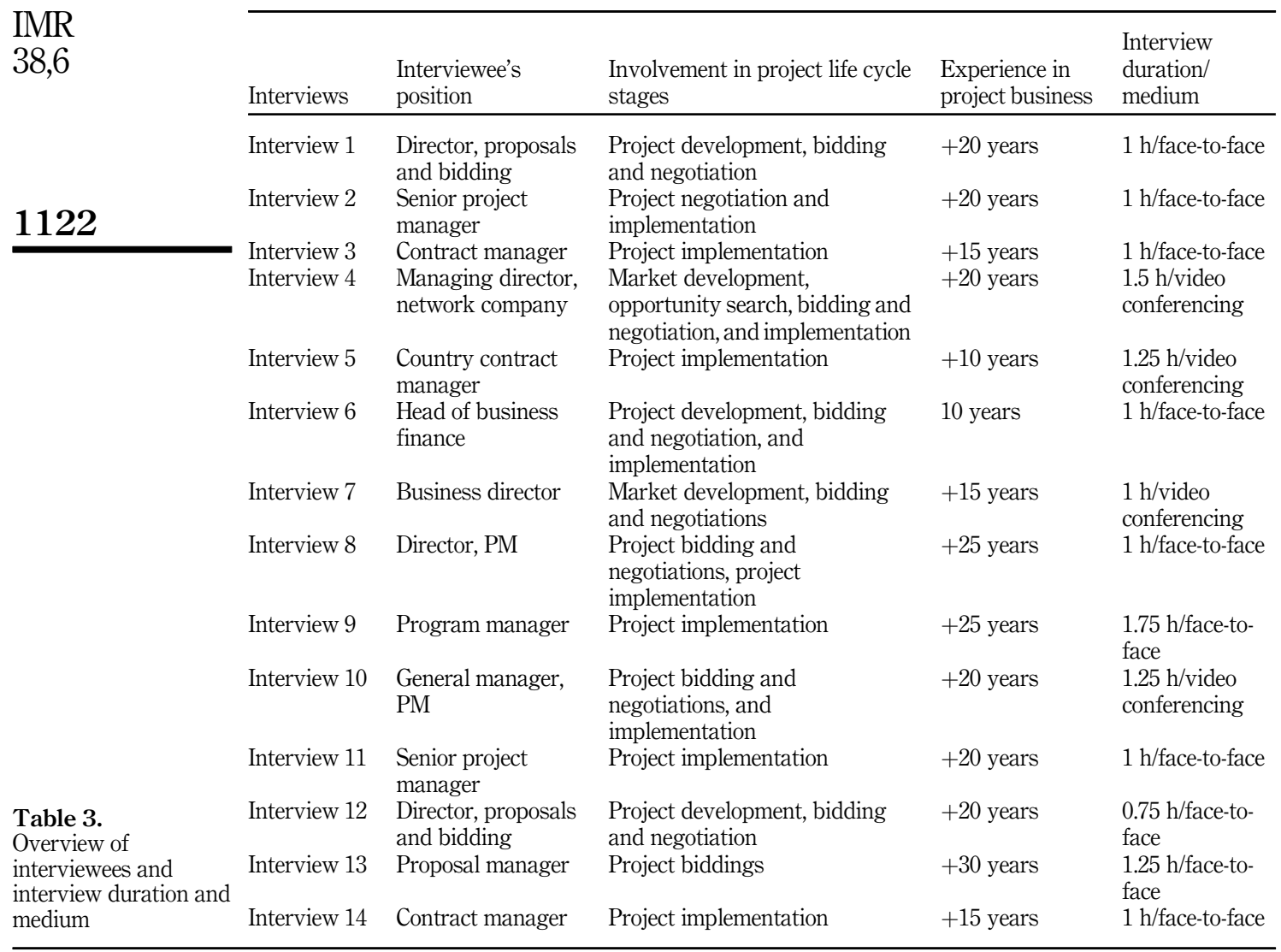

findings were cross-verified to draw final results. According to Langley (1999), contextual details in narrative analysis offers sense-making of the hidden realities, which extant research on political risk management has not employed so far.

\subsection{Research context and embedded cases}

This research investigates six energy infrastructure projects (EIPs) in EMs as embedded cases (Yin, 2003) of an MNE from North Europe. Multiple embedded cases from a single MNE context provided us a consistent boundary condition for interpreting the data and facilitated the findings' analytical generalization (Teagarden et al., 2018). The case company, here called Energy Co., is an OEM that operates globally through its network offices in more than 60 countries. Major manufacturing facilities of the Energy Co. are in Europe and Asia. The business focus of Energy $C_{0}$. is on delivering EIPs in developed as well as in EMs. Energy Co. has positioned itself as one of the key players in the energy market with its global business focus.

Based on the guidance from Söderlund and Tell's (2009) study, Energy Co. can be considered as a P-form enterprise whose focus is on the integration of technology-based products and services from its various functional and manufacturing units (Melkonian and Picq, 2011). Hence, Energy Co. differentiates itself as a solution provider of infrastructure 
projects comprising of large complex product systems (Kowalkowski et al., 2015). Several of the infrastructure projects implemented by Energy Co. fulfill Kardes et al. (2013) criteria for a megaproject. Meanwhile, Energy Co. has two dedicated business divisions, one for the offshore infrastructure projects and one for the onshore infrastructure projects. All the six cases investigated in this research are onshore EIPs in EMs. Detailed contextual characteristics of these projects are outlined in Table 4.

3.2.1 Case A. In Case A, Energy Co. had a project agreement with the private-owned enterprise (POE) in Bangladesh. Under the agreement, Energy Co. supplied the equipment of EIP to the buyer. However, the buyer had a separate contract with a local company who installed the EIP. In addition, the local office of Energy Co. supervised the installation of EIP and tested EIP once it was completed (see (i) in Figure 2).

3.2.2 Case B. In Case B, a POE earned the contract from a state-owned enterprise ( $\mathrm{SOE}$ ) in Indonesia to deliver a complete EIP. POE formed a CJV with Energy Co. for the delivery of EIP. Under the CJV agreement, POC and Energy Co. built and transferred the complete EIP to the SOE. In addition, the local office of Energy Co. supervised the installation of EIP and tested once EIP was ready (see (ii) in Figure 2).

3.2.3 Case C. In Case C, Energy Co. supplied a complete EIP to the EJV formed between SOE and POE in Brazil. Further, Energy Co.'s network office in Brazil supervised EIP's installation and tested EIP once it was ready. However, in this case, Energy Co. also engaged the local sub-contractors from Brazil for the installation and construction of the EIP (see (iii) in Figure 2).

3.2.4 Case D. In Case D, Energy Co. had a project agreement with the POE in Jordan. Under the agreement, Energy Co. supplied a complete EIP to the buyer. Further, Energy Co. also engaged the local sub-contractors from Jordan to install and construct the EIP (see (iv) in Figure 2).

3.2.5 Case E. In Case E, Energy Co. supplied a complete EIP to the EJV formed between Energy Co. and POE in Pakistan. So, Energy Co. supplied and co-owned the EIP. Further, Energy Co.'s network office in Pakistan supervised EIP's installation and tested EIP once it was ready. However, Energy Co. also engaged the local sub-contractors from Pakistan for the installation and construction of the EIP (see (v) in Figure 2).

3.2.6 Case F. In Case F, Energy Co. formed a CJV with an SOE builder in Indonesia that earned a contract from an SOE utility to deliver a complete EIP. Therefore, Energy Co. along with the SOE builder together supplied the complete EIP to the SOE utility. Further, Energy Co.'s network office in Indonesia supervised the installation of EIP and tested of EIP once it was ready (see (vi) in Figure 2).

\section{Study findings}

Based on interview data from respondents, we have attempted in Figure 3 to provide an overview of the reduction of political uncertainty and its transition to political risk during the four stages of project development.

The graph (Figure 3) suggests that the political uncertainty is high during the initial stage of "market development and opportunity search" and starts decreasing substantially at the end of this stage as more information and knowledge about the political environment of target EM become available, and therefore, political uncertainty is converted into political risk. Therefore, at the commencement of the second stage of "project preparation and development," an MNE identifies the political risks and decides the mechanisms for managing them.

Political risks in EMs are a reality, and our case company deployed several mechanisms to mitigate those risks in the case projects to safeguard the promised return on investment (ROI). Energy Co., with several years of experience of IPOs in EMs, has developed its 
IMR

38,6

\section{4}

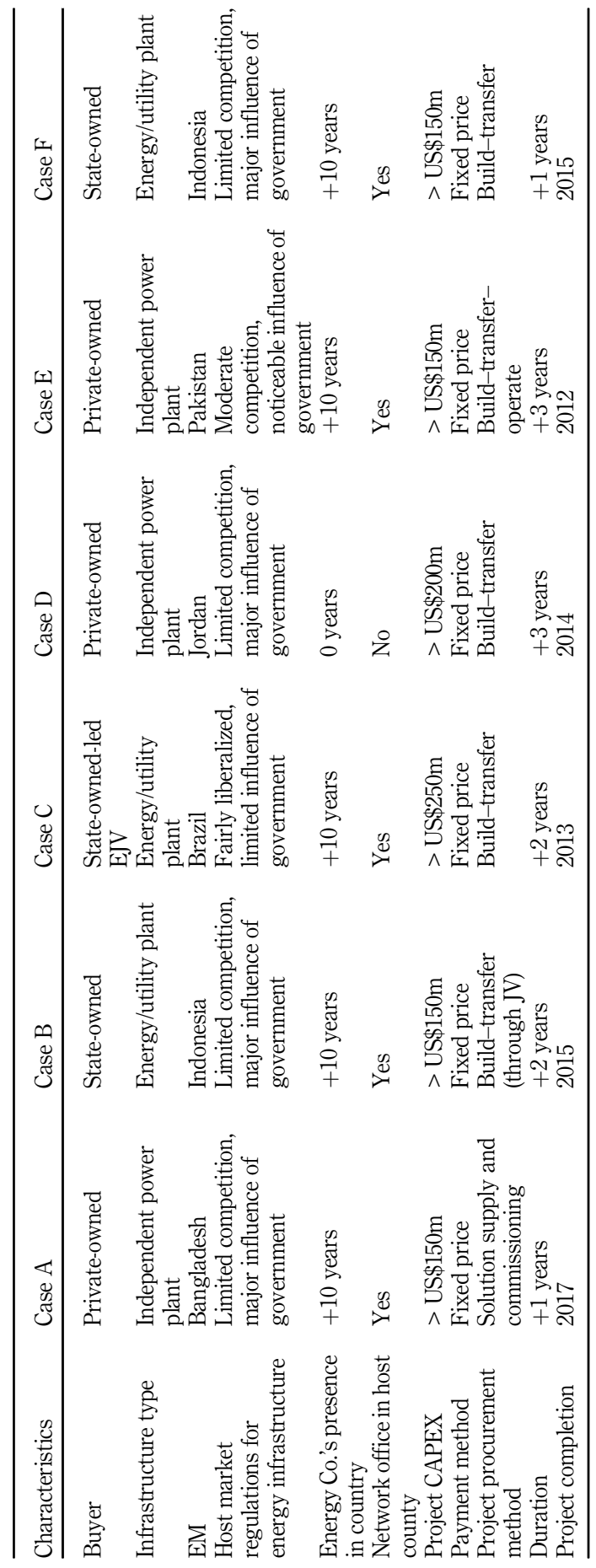

Table 4.

Summary of research case megaprojects 


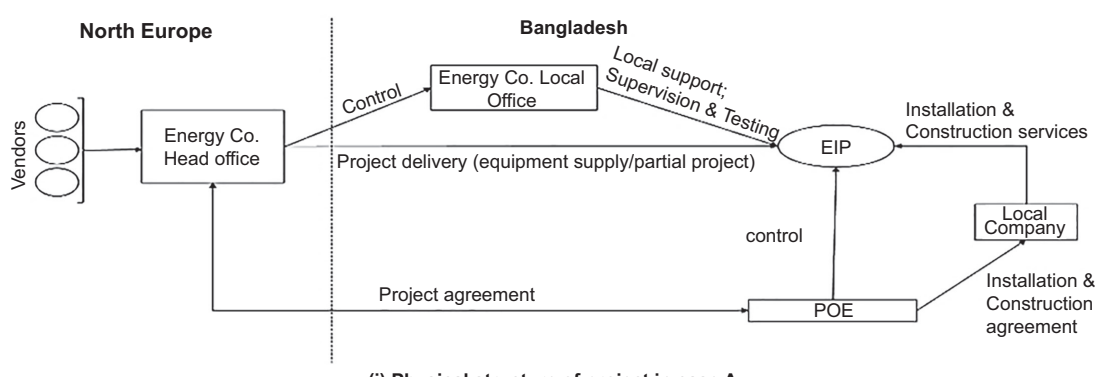

Political risk management

(i) Physical structure of project in case A

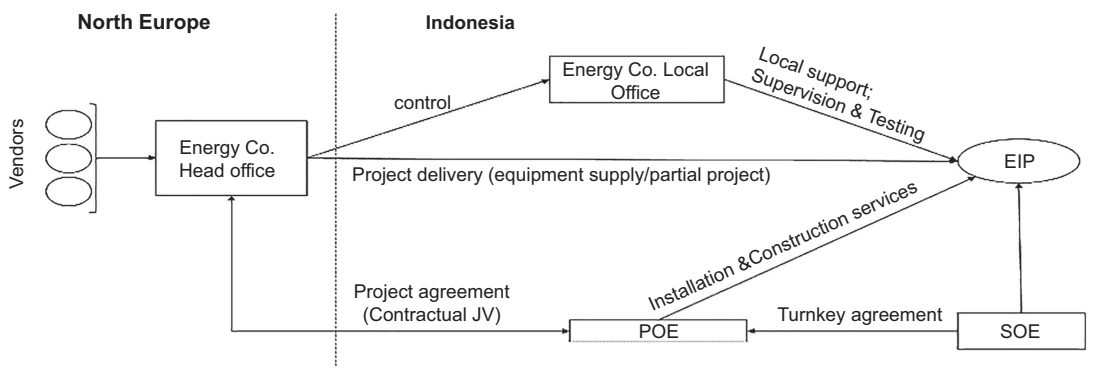

(ii) Physical structure of project in case B

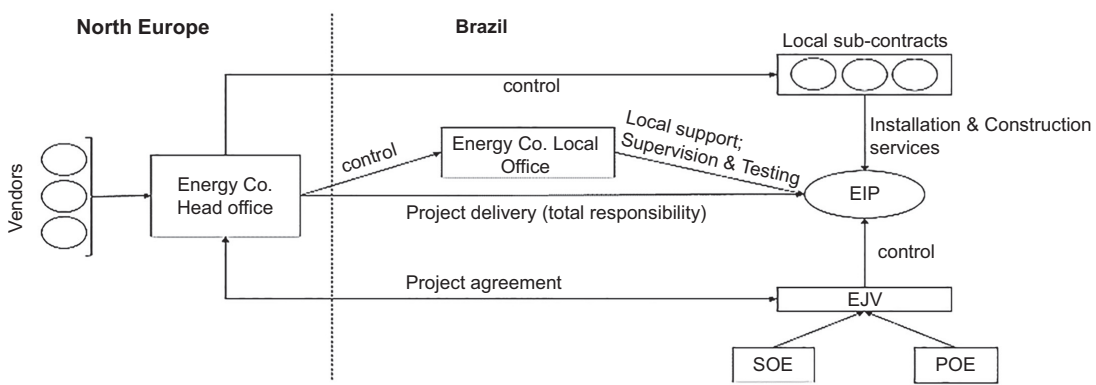

(iii) Physical structure of project in case $\mathrm{C}$

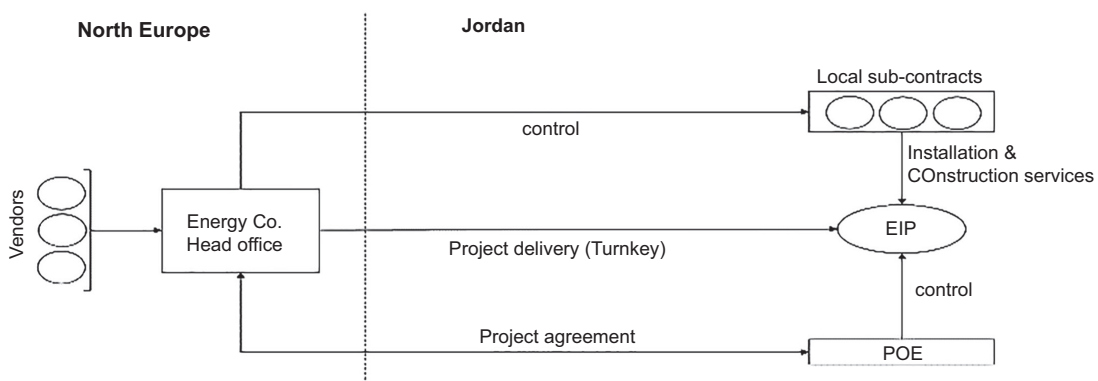

(iv) Physical structure of project in case D

Figure 2.

Physical structure of case projects 
IMR

38,6

1126

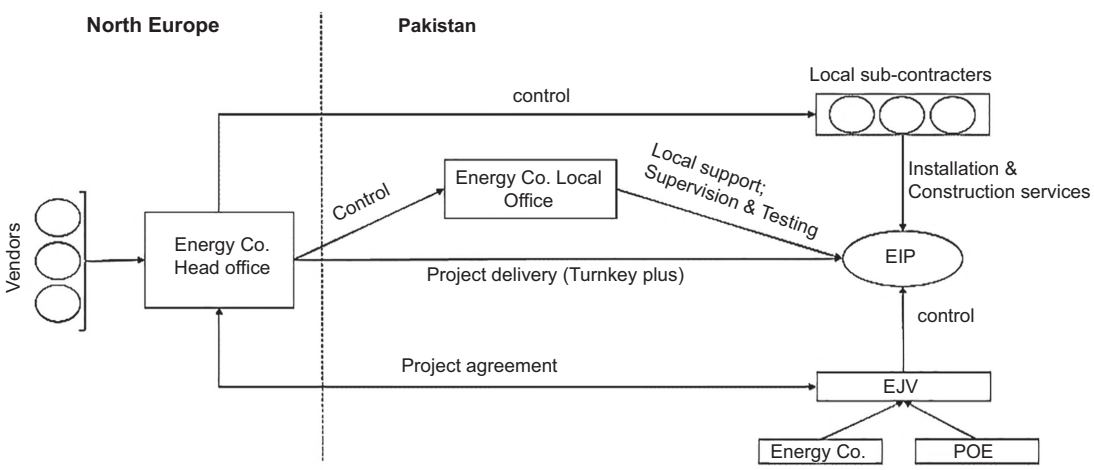

(v) Physical structure project in case $\mathrm{E}$

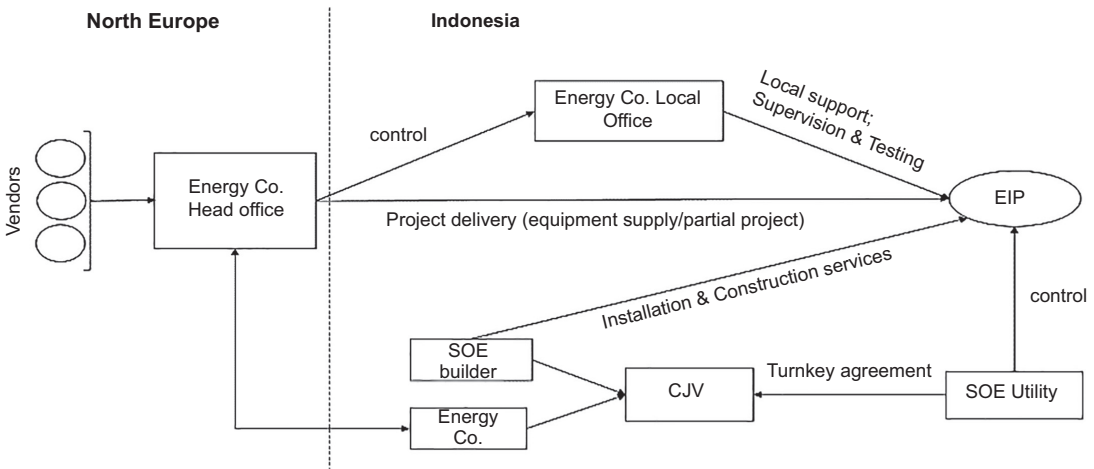

(vi) Physical structure project in case $\mathrm{F}$

Figure 2.

Note(s): Energy infrastructure project (EIP); State owned enterprise (SOE); Contractual joint venture (CJV); Equity joint venture (EJV)

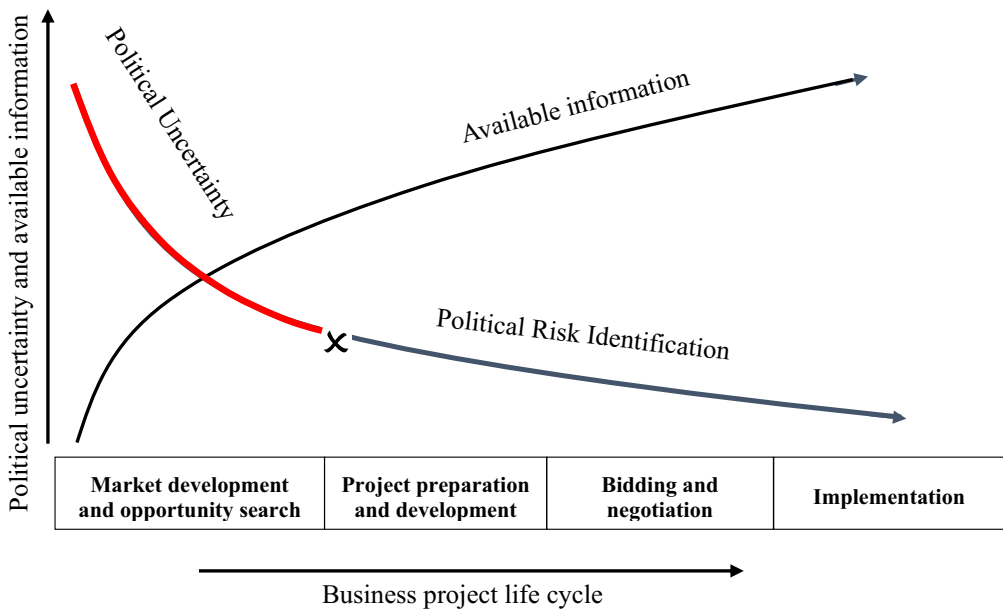

Figure 3.

Uncertainty and its transition to risk during the four stages of project development 
capabilities of identifying project risks, including political risks (Cova and Holstius, 1993). Most of our interviewees stated: "Political risk is the biggest risk for project business when you are in emerging markets," and it was verified from the case project data (i.e. data from case company's risk registers and mitigation plans). Further, it was confirmed from interviews that Energy Co. identifies the political risks and decides the mechanisms to reduce them during the second stage of the project life cycle (Figure 3). Interviewees also confirmed that "all the identified political risk factors in the literature review of this paper are relevant for assessing [i.e. they are evaluated for identifying] political risks for the energy infrastructure projects." Table 5 lists the examples of political risk perceptions quoted during the interviews. However, interviewees revealed that different countries have different challenges, and what political risks are relevant depends on the "ground realities" and "historical events."

\subsection{Political risk factors}

Though Energy Co. evaluates all the political risk factors identified in this paper's literature review, the relevance of political risk factors in each EM depends on the ground realities of that particular EM. Political risks in EMs that were of concern to most of the respondents, in five of the six case projects in EMs, are corruption and bribes, political regime change, risk of labor unions and protests, and social violence and strikes. Table 6 summarizes the key political risks in EMs. This stresses that these political risks are pretty common in all EMs. Further, political risks that were of concern to some respondents, in four of the six case projects in EMs, are discriminatory taxation and change in tax regulations, restriction on the number of expatriate employees, excessive demands and variations in a project from the host government over time, terrorism at site location, weakly enforced laws and regulations, and security problems and risk of a violent attack on project site. This stresses that these political risks are salient concerning few EMs. Also, some political risks were of concern to few respondents, in $\leq$ three of the six case projects in EMs, are delay in the approval of permits, profit remittance and exchange restrictions, import restrictions, unstable government policies impacting the project, enforced renegotiations of contract by the host government, anti-project demonstrations by public, contract repudiation and an outbreak of inter-state war. However, there was no concern of nationalism or confiscation in any of the case projects in EMs. Overall, we conclude that some political risk factors are relevant in all EMs, some in few EMs and one is not relevant in any of the investigated EMs.

\subsection{Applied mitigation mechanisms}

After identifying the political risks in EMs, mechanisms are employed to mitigate those political risks. The mechanisms that many respondents favored to mitigate political risks, in $\geq$ four of the six case projects in EMs, are aligning objectives with the host government, fixedterm payment method, developing trust-based informal networks with local business and people of the host government, progressive payments and obtaining payment guarantee from local or global financial and commercial institutes. Especially the last two mechanisms, favored by Energy Co., are new findings, which prior literature on political risk management have not addressed. Table 7 summarizes the employed mechanisms to mitigate political risks. Further, in three of the six case projects, an arm's length classical contract with a target country firm was employed to reduce political risks. In addition, mechanisms that some respondents favored to mitigate political risks, in two of the six case projects in EMs, are CJV formation with a target country firm and seeking a higher project price to cover contingencies. In addition, one of the six case projects, an EJV with a target country firm and buying PRI were employed to mitigate political risks. Overall, we conclude that political risk is subject to constraints from several mechanisms, where some mechanisms are
Political risk management 
1 - Corruption and bribes

\section{8}

2 - Delay in approval of permits

3 - Nationalism or confiscation

4 - Profit remittance and exchange restrictions

5 - Import restrictions

6 - Discriminatory taxation/change in tax regulations

\section{7 - Political regime change}

(a) "We have to follow our code of conduct. . . and it can be a reason that a project never materializes [for us]"; (b) "This was a hot topic during project development and sales... project owner did special training arrangements for us to understand this topic [about the project country]"; (c) "We force our [local] partners to comply to those rules [Energy Co.'s code of conduct]"; (d) "If our competitors [in countries with this high risk] do not follow the same [European] rules then we are out. . . there is saying that "kind kids care waiting and left without"; (e) "It was directly negotiated project [an example] with an SOE. [due to some compliance issues] it was decided that Energy $\mathrm{C}_{0}$. will not make direct deal with SOE"

(a) "In countries with high corruption] we do not want to do this";

(b) "They keep in asking you different documents so the approvals etc. will be delayed"; (c) "You want your permit approved but there is always an official way and there is also a 'faster way' to it. . . but for us there is one way to do it and that is to do it by the book"

(a) "It is important to consider [already during development phase]"; (b) "There are some historical examples. . in country [name] it may not a problem anymore"

(a) "If the country runs out of foreign exchange [reserves] so you cannot take back you cash from the country... so you have to have ways to mitigate this. You do this during project development phase otherwise those will affect you later on"; (b) "You need to take into account what are the national limitations in transferring funds to our home country bank accounts for example, I have heard that in [country name] they implemented that you cannot transfer money outside the country and if you manage to transfer then there are very high taxes"

(a) "They want us to find local suppliers for non-critical items, and if those materials are available locally then there are qualityrelated challenges which need extra arrangements from our side. . . They have a way to blacklist foreign countries if the local content of certain \% is not used"; (b) "They ask different things [to include] in the [import documentation name]. . . an indirect way to restrict"

(a) "Taxation is a big risk even having local office, we still need to verify if they are entitled to do this as a local company"; (b) "Country decides they have a problem of managing the fiscal budget. So they raise taxes and your profit as investor decreases and it can reduce your ROI, unless you mitigate this risk in development phase"

(a) "It is difficult you have to trust that the agreement you signed will [with]stand"; (b) "The new projects should be up and running in very short periods [less time is available for implementation], and before the next elections"; (c) "Next year there are

elections. . . they [politicians] are busy with the energy industry to make new plans, so getting new projects is difficult"; (d) "It is political risk due to which many projects go on hold or [otherwise] the project business slows down when the new governments come into power"
Table 5.

Political risk perception by interviewees 


\section{Political risk factors}

8 - Restriction on the number of expats

9 - Contract repudiation

10 - Excessive demands and variations in project from the host government over time (contract violations)

11 - Enforced renegotiations of contract by the host government

12 - Unstable government policies impacting the project

13 - Unstable local transportation rules and regulations

14 - Terrorism at site location

15-Risk of labor unions/labor protests

16 - Outbreak of inter-state war

17 - Social violence/strikes

\section{Quotations}

(a) "We had to make [employment] contracts of foreigners [with our branch office] and then also had to hire locals too"

(a) "Usually the need for electric power is increasing [in emerging markets]. So, we do not see this as a risk factor"; (b) "Hardly ever, but there are delays in starting of the signed contract. It happened once in my experience. . . customer was not able to arrange equity in the agreed currency"

(a) "They do understand that they have power... when it comes to commercial part they have [country's] annual budget they are ties to. Sometimes depending on their budget figures, they start to find errors in our invoice, such as the difference of few decimals. They typically do not tell us immediately [as per the contract]. . . and we never get what is official [way]"; (b) "If the team are not knowledgeable then the bidder suffers because then they [regulators] can ask make unnecessary requirements and may try to use the space for situation which is not in compliance with certain rules”; (c) “... Yes [in country] contract is helpful when there is extreme conflict"; (d) "Letter of credit losses its meaning, for example, when the invoice has to be approved the customer in some countries like some of our customers are government owned company. In that case ways for limitation are very limited"

(a) "[signed] contract is not important for them... you have to have courage to sit with them to discuss again and again ..."; (b) "They renegotiate all the time. It is their way of working" (a) Government policy is a trigger for developing [energy infrastructure] projects..."This develop trust or distrust..."; (b) "But for the projects in sales pipeline, the political policies uncertainty then the investment decisions are hold"; (c) "They have track record for handling foreign investors: clear rules with proven [implemented] projects"

(a) "We outsource the whole transportation of our equipment to an international firm. But they were not prepared because that company was not understanding the local requirements"; (b) "Every regional office had their own way of working. . . each time you have different dimension to the communication. The SOE stakeholders were not aligned and they were control freaks and want to have you on knife edge"

(a) "We did some studies and involved our security manager [local office support] to make plan"; (b) "and also sometimes that which part of the country you are doing project. For example, in case project [name of project] ..."

(a) "We usually do it during project development phase and get inputs from various [potential] sub-contractors"; (b) "Every year [period name] there is a raise of salaries but due to [... ] there were layoffs instead of wage raise. We can't do anything but to plan our project [works] accordingly...we also involved consortium leader for this"

(a) "It is something you consider [already during project development], but you do not spend much time on it"

(a) “... Then everything stops. It is not easy to move. . For project [name] meeting, I was in [county name] when people come out on rods for strike. I asked the customer to please come to my hotel because I cannot move outside"
Political risk management 
IMR

38,6

1130

19-Anti-project demonstrations by public

20 - Security problems/risk of violent attack on project site

18 - Weakly enforced laws and regulations

\section{Quotations}

(a) "It is a problem not impact on our business because energy sector regulations are clear and enforced"; (b) "We always try to use a neutral country for applicable law. We prefer that it is the buyer country legislation is not applicable. We try to avoid the need to go to the local court ..."

(a) "If you are developing a project, you leave it to a later stage. [But] if the site is such a region then you have to consider how to move people out [in such situations]"; (b) "The local community started to though rocks and stopped us [to continue work].

Project work was suspended for seven days"

(a) "The first most important think come to my mind is the people you are going to bring to that country"; (b) "We stay at designated areas [in the city] and then the timing and schedules of our local travel and routing need to altered. . Don't expose yourself much"

Table 5.

\begin{tabular}{|c|c|c|c|c|c|c|}
\hline Political risk factors & $\begin{array}{l}\text { Case } \\
\text { A }\end{array}$ & $\begin{array}{l}\text { Case } \\
\mathrm{B}\end{array}$ & $\begin{array}{l}\text { Case } \\
\mathrm{C}\end{array}$ & $\begin{array}{l}\text { Case } \\
\mathrm{D}\end{array}$ & $\begin{array}{l}\text { Case } \\
\mathrm{E}\end{array}$ & $\begin{array}{l}\text { Case } \\
\mathrm{F}\end{array}$ \\
\hline 1 - Corruption and bribes & レ & $\boldsymbol{\swarrow}$ & $\boldsymbol{\nu}$ & レ & - & $\boldsymbol{\nu}$ \\
\hline 2 - Delay in approval of permits & $\boldsymbol{\nu}$ & $\boldsymbol{\nu}$ & $\boldsymbol{\nu}$ & - & - & - \\
\hline 3 - Nationalism or confiscation & - & - & - & - & - & - \\
\hline 4 - Profit remittance and exchange restrictions & - & $\boldsymbol{\nu}$ & $\boldsymbol{\nu}$ & $\boldsymbol{\nu}$ & - & - \\
\hline 5 - Import restrictions & - & - & $\boldsymbol{\nu}$ & $\boldsymbol{\nu}$ & - & $\boldsymbol{\nu}$ \\
\hline 6 - Discriminatory taxation/change in tax regulations & $\boldsymbol{\nu}$ & _ & $\boldsymbol{\nu}$ & - & $\boldsymbol{\nu}$ & $\boldsymbol{\nu}$ \\
\hline 7 - Political regime change & $\boldsymbol{\nu}$ & $\boldsymbol{\nu}$ & レ & - & $\boldsymbol{\nu}$ & $\boldsymbol{\nu}$ \\
\hline 8 - Restriction on the number of expatriate employees & $\boldsymbol{\nu}$ & - & $\boldsymbol{\nu}$ & $\boldsymbol{\nu}$ & - & $\boldsymbol{\nu}$ \\
\hline 9 - Contract repudiation & $\boldsymbol{\nu}$ & - & - & - & - & - \\
\hline $\begin{array}{l}10 \text { - Excessive demands and variations in project from } \\
\text { the host government over time (contract violations) }\end{array}$ & $v$ & $v$ & - & $v$ & - & $v$ \\
\hline $\begin{array}{l}11 \text { - Enforced renegotiations of contract by the host } \\
\text { government }\end{array}$ & - & $v$ & - & $v$ & - & - \\
\hline $\begin{array}{l}12 \text { - Unstable government policies impacting the } \\
\text { project }\end{array}$ & - & $v$ & $v$ & - & $v$ & - \\
\hline $\begin{array}{l}13 \text { - Unstable local transportation rules and } \\
\text { regulations }\end{array}$ & - & $v$ & $v$ & $v$ & $\nu$ & - \\
\hline $14-$ Terrorism at site location & $\boldsymbol{\nu}$ & $\boldsymbol{\nu}$ & - & $\boldsymbol{\nu}$ & $\boldsymbol{\nu}$ & _- \\
\hline 15 - Risk of labor unions/labor protests & $\boldsymbol{\nu}$ & $\boldsymbol{\nu}$ & $\boldsymbol{\nu}$ & $\boldsymbol{\nu}$ & - & $\boldsymbol{\nu}$ \\
\hline 16 - Outbreak of inter-state war & - & - & - & - & $\boldsymbol{\nu}$ & - \\
\hline 17 - Social violence/strikes & $\boldsymbol{\nu}$ & $\boldsymbol{\nu}$ & $\boldsymbol{\nu}$ & $\boldsymbol{\nu}$ & $\boldsymbol{\nu}$ & - \\
\hline 18 - Weakly enforced laws and regulations & - & $\boldsymbol{\nu}$ & $\boldsymbol{\nu}$ & - & $\boldsymbol{\nu}$ & _ \\
\hline 19 - Anti-project demonstrations by public & $\boldsymbol{\nu}$ & - & - & $\boldsymbol{\nu}$ & - & - \\
\hline $\begin{array}{l}20 \text {-Security problems/risk of violent attack on project } \\
\text { site }\end{array}$ & $v$ & $v$ & - & $v$ & $v$ & - \\
\hline
\end{tabular}

important response mechanisms to mitigate political risks in all EMs and some mechanisms are employed for mitigating the political risks in some EMs.

\subsection{Analytical framework for political risk mitigation in emerging markets}

We draw two key conclusions about the applicability of political risk management mechanisms. Firstly, some political risk factors are found relevant in all EMs, some in few 


\begin{tabular}{|c|c|c|c|c|c|c|c|}
\hline Applied mechanisms to mitigate the political risks & $\begin{array}{l}\text { Case } \\
\mathrm{A}\end{array}$ & $\begin{array}{l}\text { Case } \\
\text { B }\end{array}$ & $\begin{array}{l}\text { Case } \\
\mathrm{C}\end{array}$ & $\begin{array}{l}\text { Case } \\
\text { D }\end{array}$ & $\begin{array}{l}\text { Case } \\
\mathrm{E}\end{array}$ & $\begin{array}{l}\text { Case } \\
\mathrm{F}\end{array}$ & $\begin{array}{l}\text { Political risk } \\
\text { management }\end{array}$ \\
\hline Aligning objectives with the host government & - & $\boldsymbol{\nu}$ & $\boldsymbol{\nu}$ & $\boldsymbol{\nu}$ & $\boldsymbol{\nu}$ & $\boldsymbol{\nu}$ & \\
\hline $\begin{array}{l}\text { Developing trust-based informal networks with local } \\
\text { business and people of the host government }\end{array}$ & $\nu$ & $\nu$ & $v$ & $\nu$ & $\nu$ & $\nu$ & \\
\hline EJV formation with a target country firm & - & - & - & - & $\boldsymbol{\nu}$ & - & \\
\hline CJV formation with a target country firm & - & $\nu$ & - & - & - & $\nu$ & 1131 \\
\hline $\begin{array}{l}\text { Arm's length classical contract with a target country } \\
\text { firm }\end{array}$ & $\nu$ & - & $\nu$ & 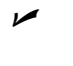 & - & - & \\
\hline Buying PRI & - & - & - & - & $\boldsymbol{\nu}$ & - & \\
\hline $\begin{array}{l}\text { Obtaining payment guarantee from local or global } \\
\text { financial and commercial institutes }\end{array}$ & $\nu$ & - & - & $\nu$ & $\nu$ & $v$ & $\begin{array}{r}\text { Table } 7 . \\
\text { Summary of the }\end{array}$ \\
\hline Seeking a higher project price to cover contingencies & - & - & - & - & $\boldsymbol{}$ & $\boldsymbol{\nu}$ & employed mechanisi \\
\hline Payment method - fixed term & $\boldsymbol{\nu}$ & $\boldsymbol{\nu}$ & $\boldsymbol{\nu}$ & レ & $\boldsymbol{\nu}$ & $\boldsymbol{\nu}$ & to mitigate the politi \\
\hline Progressive payments & $\boldsymbol{\nu}$ & $\boldsymbol{\nu}$ & $\boldsymbol{\nu}$ & $\boldsymbol{\nu}$ & $\boldsymbol{\nu}$ & $\boldsymbol{\nu}$ & risks in $\mathrm{E}$ \\
\hline
\end{tabular}

EMs and the risk of "nationalism and confiscation" is not found relevant in any of the investigated EMs. However, it is important to mention that Energy Co. evaluates the risk of "nationalism and confiscation" during the second stage of "project preparation and development." Secondly, political risks are subject to constraints from several mechanisms, where some mechanisms are used in all EMs to mitigate political risks, and some are used only in a few EMs to mitigate the political risks. In the following, we propose the analytical framework of political risk management based on the case findings, and we further discuss the applied mechanisms with reference to the prior literature (Figure 4).

The study sought to explore the mechanisms used by the Energy Co. to manage the political risks in six case projects in five EMs. The proposed analytical framework (Figure 4), based on the findings of the case projects of Energy Co., suggests that two mechanisms from the SET, namely, aligning objectives with the host government and developing trust-based informal networks with local business and people of the host government, are used to reduce political risks. Further, political risks in EMs can also be reduced by three mechanisms from the TCT, namely, EJV formation with a target country firm, CJV formation with a target country firm and arm's length classical contract with a target country firm. Two mechanisms from finance-based
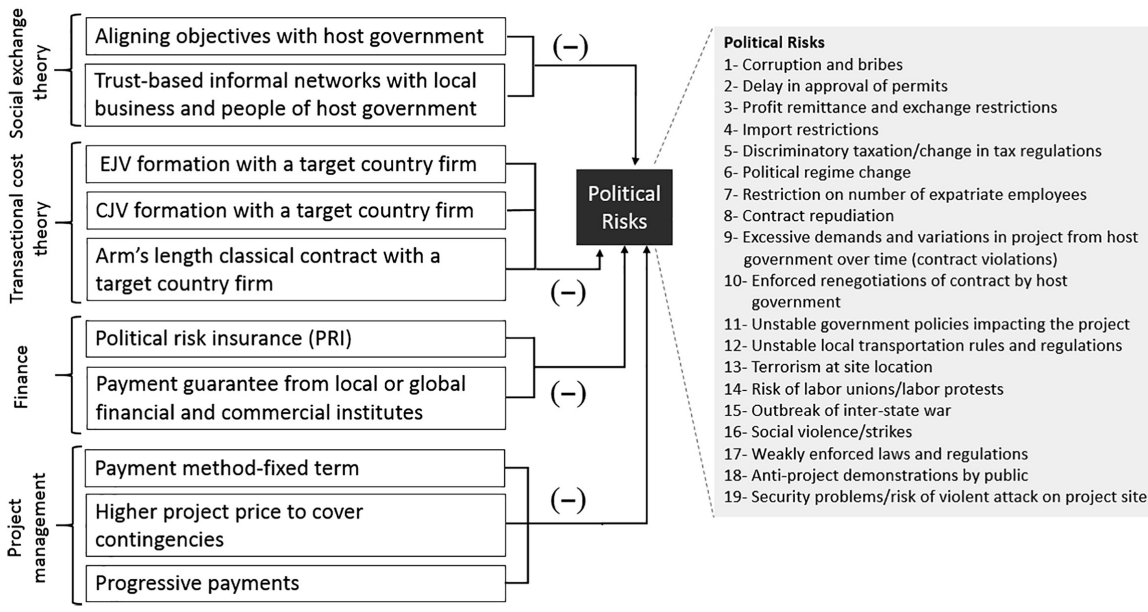

Figure 4.

The upgraded analytical framework

for political risk management in EMs (based on the findings of the case projects) 
IMR

38,6

literature, namely, buying PRI and obtaining payment guarantee from local or global financial and commercial institutes, also mitigate political risks in EMs. Finally, three mechanisms from the PM literature, namely, fixed-term payment method, seeking a higher project price to cover contingencies and progressive payments, also reduce political risks in EMs.

4.3.1 Aligning objectives with the host government. The use of this mechanism was observed in five of the six case projects of Energy Co. to reduce the political risks in EMs. This mechanism's importance is obvious since the main agenda of the governments in EMs is to develop the local infrastructure to sustain the higher economic growth rate and improve its social performance (e.g. Luo, 2004). Therefore, if the DMNEs contribute to this agenda of governments by delivering infrastructure projects, employing locals and embracing corporate social responsibility, governments in EMs will cooperate with DMNEs, which will reduce the political risks in the EMs. Reimann et al. (2012) further endorse this by suggesting that host governments cooperate with MNEs who engage in the social and economic development of the country, in particular, because it also helps the governments to secure their own credibility with their respective stakeholders, such as voters. The following quotes illustrate the importance of this mechanism:

(1) "It is getting more and more weight for financial institutes, and it is a critical issue for owner side. If the project you are bidding does not contribute to the social and economic growth of the country then what will happen to the project if country run short of cash? And if your project is not on high priority then your project is going to end up in a waiting queue."

(2) "The more important you project is for the prosperity of the country, the more priority your project is going to get from the government as well."

4.3.2 Developing trust-based informal networks with local business and people of the host government. The importance of this mechanism in mitigating political risks in EMs was observed in all case projects. Energy Co. opened local network offices in all EMs, except one EM. These network offices in EMs hired local employees at different hierarchical positions, which brought trust-based informal networks with local business and government authorities. This is in line with the logic of the SET that signifies the importance of developing trust-based relationships in business (Luo 2001, 2004). Cavusgil et al. (2013) also argue that business in EMs is dependent on relationships, and having trust-based relationships with people of the host government gain precedence in EMs. The following example quotes illustrate the importance of this mechanism in reducing political risks:

(1) "It is very important to have branch office - the companies with branch office are more successful than the competitors. Having a presence locally. Because it help handling issues related to payments and handling the government authorities..."

(2) "A lot goes with personal relations which starts already from universities [i.e. relationship of employees in local office]. The relationship continues as they are always in a very' tight community'... you can call it a kind of lobbing. So we already start identifying risks during sales phase and we involve internal functions [local office] and resources."

(3) "The more unstable the more unreliable things are, it is most important to have personal relations. Strong contract does not help you; the bigger the political risks are the important is to build informal relationships."

4.3.3 Formation of equity joint venture, contractual joint venture and classical contract with a target country firm. An EJV with a target country firm was used in one case project, and a CJV with a target country firm was used in two case projects to mitigate the political risks in EMs. 
The importance of local partner in the form of an EJV and a CJV was important because local partners brought the knowledge of the local political environment that helped Energy Co. to reduce the political risks. This endorses the logic of the TCT to form EJVs and CJVs with target country firms to mitigate the political risks (e.g. Lopez-Duarte and Vidal-Suarez, 2010; Meschi, 2005). The following example quotes illustrate the importance of this mechanism in reducing political risks:

(1) "They have track record for handling foreign investors: clear rules with proven [implemented] projects. But in some countries, you cannot go alone in bidding, without local partner on-board.”

(2) "We bring technical expertise and they bring local expertise to handle the political risk factors. But in consortiums, it works when both consortium partners have same objective."

(3) "Getting some special permits. . if you tell them the door in front of us is locked. Could you please do something? Then only them by calling [to the concerned permit issuing authority] the problem get resolved."

However, it was observed that in three of the case projects, the political risks in EMs were substantial, and therefore, Energy Co. used classical contracts with target country firms to mitigate the political risks in EMs. This also endorses the logic of the TCT that when external risks, including the political risks, are too high, and therefore, resulting risk of local partner's opportunism is high, then instead of forming a CJV or EJVs, MNEs should undertake classical contracts with target country firms (Ahmed et al., 2002; Mullner, 2016) to mitigate the political risks. The following quote illustrates the importance of this mechanism in reducing political risks:

(1) "Contract is important-Contracts are important for Energy Co. and for our customer we try to minimize the effect of political risks during contract negotiations. We also split contracts in offshore and onshore to limit the impacts within the host company."

4.3.4 Buying political risk insurance (PRI). PRI was used only in one case project to mitigate the political risks in the EM. Finance literature suggests that PRI covers and compensates the losses occurring to the MNEs investment due to the direct and indirect actions of government (e.g. Lessard, 1996; Voelker et al., 2008; Zhang and Wei, 2012), and therefore, more the EM's political environment is risky, the more the DMNEs should seek PRI to mitigate. However, it was noted that some respondents were not aware of PRI, and some, who were aware, mentioned the higher costs associated with procuring PRI. The following quote illustrates the importance of this mechanism in reducing political risks:

(1) "We have some sort of political risk insurance. In reality, it can be an insurance or another policy you involve in a project. For example, we had political risk insurance policy through a financial agency [name of institute]. The insurance become effective at financial closing of the project, essentially at the implementation [phase of project]."

4.3.5 Obtaining payment guarantee from local or global financial and commercial institutes. The importance of this mechanism in mitigating political risks in EMs was observed in four case projects. However, while searching the theoretical roots of this construct, we noticed that very limited literature (e.g. Mullner, 2016; Sawant, 2012) has discussed its role in mitigating overall risks. We noted that Energy Co. networked with local or global reputable financial and commercial institutes to secure payment for its projects and reduce the political risks in EMs. The following example quotes illustrate the importance of this mechanism in reducing political risks:
Political risk management 
IMR

38,6

\section{4}

(1) "If you look at different banks and financial institutes, they may have different risk appetites in different countries. If you see [in their evaluation that] country is having red flags from many institutes then it is red flag for the project itself. It means that the project is not bankable and you have to ask that if banks are not going to invest then why we should!"

(2) "One of the way we try to mitigate political risk is by [taking on] board, someone like World Bank as partner [in the project]. They have special status in certain countries that go beyond a single project. They have bilateral agreements with governments. If there is a problem they [global financial and commercial institutes] will be the first one to be paid. If you work with a partner like that then you take a lot of comfort. That is definitely one of way of mitigation you need to consider."

4.3.6 Payment method - fixed term. The importance of this mechanism in mitigating political risks in EMs was observed in all case projects. The PM literature (Luostarinen and Welch, 1990, p. 139) lists three different methods of payment to the supplier: fixed price, cost plus fixed fee and target price. The conventional wisdom from the PM literature suggests that at high political risks, cost plus fixed fee and target price are the best methods to manage these risks for project suppliers (e.g. Turner, 2001). However, Energy Co. instead used a fixed price method that, according to the PM literature, suits to the buyer. All respondents stressed the importance of using this mechanism because of several reasons: sever competition for seeking EIPs, the role of contract to cover the cost of contingencies to support the fixed cost payment and customer care. The following example quotes illustrate the importance of this mechanism in reducing political risks:

(1) "[In Energy Infrastructure markets] the owners are dictating the construction business with fixed price. . . they rotate the tender and lowest bidder wins and it means fixed price. ..Also in emerging markets, the financing banks are putting roof on the costs therefore fixed price is the preferred method."

(2) "If project is delayed due to buyer. . .you need to have some kind of formula based on which you can recalculate the price with help of contract. But we do not want to upset our customers with this."

4.3.7 Seeking a higher project price to cover contingencies. This mechanism was used in two of case projects to mitigate the political risks in EMs. Respondents stressed the importance of this mechanism to secure required profit and to protect against costs due to the political risks. But, respondents also reflected that Energy Co. does not increase price too high because it lowers the probability of winning the bid. While referring back to the PM literature, Chang et al.'s (2018) study confirms the importance of this mechanism in reducing the political risks in EMs. The following example quotes illustrate the importance of this mechanism in reducing political risks:

(1) "We have to have risk mitigation [costs] on top of the costs and margins."

(2) "We needed more resources to help [local partner] in the project implementation. It need to be taken in to account."

4.3.8 Progressive payments. The importance of this mechanism in mitigating political risks in EMs was observed in all case projects. The PM literature (Luostarinen and Welch, 1990) differentiates between two payment methods: one-time payment and over time progressive payment. Although existing literature has not studied these types of payment methods from the perspective of political risk mitigation, this study's findings illustrate that Energy Co. utilized this mechanism in all its project in EMs to mitigate political risks. We assume that DMNEs prefer establishing control over the situation while operating under political risk. 
Progressive payments allow DMNEs to maintain the desired level of control. The following example quotes illustrate the importance of this mechanism in reducing political risks:

(1) "Payment terms stipulated in a contract is quite effective way to mitigate political risk as well. For example, what kind of financial instruments the buyer is going to use... [Upfront] advance payments are. If there is delay in the payment, then late payment interests [should be applicable]."

(2) "Safeguarding the company, the payment method is the most important. If you are paid upfront, the more the insecure situation is the more you have to ensure that money is in the account."

\section{Discussion and implications}

Although the trend of economic liberalization and demand for improved infrastructure in EMs worldwide has presented new opportunities for DMNEs to undertake IPOs for developing the infrastructure in EMs, there are also political risks in EMs. Prior research suggests that political risk is the highest-ranked risk in IPOs, which, if not managed, causes financial loss, schedule overruns and generally poor IPO performance (Chang et al., 2018; Zhang and Wei, 2012). Despite the widespread agreement among researchers regarding the importance of managing political risks (Dandage et al., 2018; Kardes et al., 2013; Mullner, 2016), little theoretical and empirical progress has been made toward exploring the nature of political risks and the mechanisms that DMNEs use to manage the political risks while undertaking IPOs in EMs. To fill this void, we adopt an abduction-based exploratory case study approach and explore the perceived political risks and their management by a DMNE when undertaking infrastructure projects in five EMs of Bangladesh, Indonesia, Brazil, Jordan and Pakistan.

Our exploratory case study reveals that DMNE identifies the political risks and decides the mechanisms to manage them at the commencement of the "project preparation and development" stage of project development. Second, our study extends the literature on the nature of political risks in EMs by revealing that some perceived political risks are common in all EMs, but some others vary between EMs depending on the ground realities of the EMs. This suggests that it is naïve to consider that perceived political risks in all EMs are the same. Therefore, it is essential to unpack the political risks in each of the EMs from the perspective of DMNEs. Third, the study extends the scope of current literature on the management of political risks by revealing that political risks are subject to constraints from several mechanisms, where DMNE uses some mechanisms in all EMs to mitigate political risks, but the use of some other mechanisms depends on the nature of political risks in each EM. This suggests that it is also naïve to consider that a DMNE uses the same mechanisms to mitigate political risks in all EMs. Therefore, it is important to unpack the mechanisms that DMNEs use to mitigate political risks in each of the EMs. In this section, we draw on the findings from six case projects of the DMNE to discuss the stage of the project life cycle at which the political risks are identified and how DMNE perceives and manages the political risk in EMs.

\subsection{Political risk identification during the project life cycle}

Prior research (Samset and Volden, 2016) has suggested that uncertainty is the highest at the initial stage of the project and diminishes and converts into risk as the project progresses due to information accumulation. Our study specifically demonstrates that the political uncertainty is high during the initial stage of 'market development and opportunity search' and starts decreasing substantially at the end of this stage as more information and knowledge about the political environment of target EM becomes available, and therefore,
Political risk management 
IMR

38,6

political uncertainty is converted into political risk. Thus, political risk is identified at the commencement of the second stage of "project preparation and development" (Figure 3).

\subsection{Perceived political risk factors}

While the existing literature implicitly assumes that political risk is universal, more recent literature (e.g. Han et al., 2018) has challenged this conventional wisdom. Our findings complement the research by Han et al. (2018) by revealing that the nature of political risks in EMs perceived by a DMNE is not the same. We find that a DMNE evaluates all 20 political risk factors identified in this paper's literature review (Figure 1). However, only four of them are present in all investigated EMs. These include corruption and bribes, political regime change, risk of labor unions and protests, and social violence and strikes. These political risks are of major concern in all investigated EMs, considering their devastating effects on the project operations. The remaining 15 political risk factors vary between EMs depending on the ground realities of the EMs, and one political risk factor (i.e. nationalism and confiscation) is not present in any of the investigated EMs (see Table 6 for detailed results). However, the respondents confirmed that nationalism and confiscation risk are evaluated before undertaking IPOs in EMs. Combining these results, we conclude that the overall nature of political risks varies between EMs though very few political risks are common in all EMs.

\subsection{Mechanisms to mitigate the political risks in emerging markets}

The findings of this research reveal that political risks are subject to constraints from several mechanisms, where some mechanisms are commonly used in all EMs to mitigate political risks, and some are used only in a few EMs to mitigate the political risks. Previous studies present four different views to manage political risks. The SET logic (Cavusgil et al., 2013; Luo, 2001, 2004) suggests the alignment of an MNE's objectives with the host government's social and economic objectives and developing trust-based informal networks with local businesses and people of the host government to reduce political risks. The TCT logic (LopezDuarte and Vidal-Suarez, 2010; Mullner, 2016; Puck et al., 2009) suggests an appropriate entry mode (i.e. choice between an arm's length classical contract, CJV and EJV with a target country firm) to manage the political risks. Finance scholars (e.g. Lessard, 1996; Voelker et al., 2008) suggest for buying PRI to reduce political risk. Finally, the PM literature (e.g. Turner, 2001) proposes the choice of appropriate payment method (i.e. choice between fixed cost, cost plus fixed fee and target price) in IPOs to reduce the political risks. However, given the complex and multifaceted nature of political risks in EMs, we adopted the view that several mechanisms are required to manage the political risks (Figure 1). Specifically, we find that two mechanisms from the SET, namely, "aligning objectives with host government" and "developing trust-based informal networks with local business and people of host government," one mechanism from the finance literature, namely, "obtaining payment guarantee from local or global financial and commercial institutes," and two mechanisms from the PM literature, namely, "fixed-term payment method" and "progressive payments," are commonly used by DMNEs to mitigate the political risks in all EMs (Table 6). The findings related to SET-proposed mechanisms are in alignment with the arguments of Cavusgil et al. (2013) and Luo (2004) that if DMNEs deliver projects that contribute to the economic and social well-off of the EMs, then governments of EMs will cooperate with DMNEs, and hence, political risks will be reduced. They also argue that EMs are mainly relationship-oriented, and therefore, developing trust-based social networks with local businesses and the host government will reduce the political risks. Therefore, this research's findings encourage the DMNEs to make a greater effort to align their objectives with EMs' governments' objectives and develop trust-based informal networks to reduce the political risks in EMs. 
Further, the importance of "obtaining payment guarantee from local or global financial and commercial institutes" in reducing political risks is a new finding for IB literature. This mechanism forces the EM governments to think twice before engaging in actions or events that could harm the business of DMNEs. In the finance literature, Mullner (2016) and Sawant (2012) highlighted its importance in reducing overall risks. Our study confirms the importance of this mechanism in reducing the political risks in EMs. The findings related to the importance of "fixed term payment method" and "progressive payments" in mitigating political risks in EMs further extend the IB literature. Unlike the conventional wisdom from the PM literature that recommends using cost plus fixed fee or target price when risk is high (Turner, 2001), we find that fixed price is the preferred method by DMNEs to reduce political risks in EMs. Using fixed price ensures the suppliers seek the project, and further, its nexus with contract reduces the political risks in EMs. In addition, the importance of "progressive payments" in reducing political risks in EMs is a new finding for the IB literature. Although the PM literature (Luostarinen and Welch, 1990) differentiates between two types of payment methods (i.e. one-time payment and overtime progressive payment), these payment methods are not specifically linked to the political risk mitigation. We find that getting upfront payment secures the DMNEs during insecure political situations.

We also find that the importance of the remaining five mechanisms varies between EMs depending on the nature of political risks in each EM. Especially, we find very limited support for TCT suggestion that DMNEs should form EJVs with target country firms when political risk is high (Lopez-Duarte and Vidal-Suarez, 2010; Puck et al., 2009) because a local partner helps to mitigate the political risk. Overall, it is found that when political risks are too high in EMs, a DMNE prefers to use arms' length contracts or CJVs with target country firms instead of forming EJVs to mitigate the political risks. At the same time, existing finance literature highlights PRI's importance in mitigating political risks because it covers and compensates the losses occurring to the DMNEs investment due to government's direct and indirect actions (e.g. Lessard, 1996; Voelker et al., 2008; Zhang and Wei, 2012). However, we find that a DMNE rarely uses this mechanism due to the higher cost of PRI. Finally, we also find that DMNEs rarely seek higher project price to cover the contingencies due to this mechanism's higher cost. In addition, we develop an overarching and comprehensive analytical framework of political risk management based on the findings of the case projects that combine several strands of literature; SET and TCT from international market entry, PM literature and finance literature (Figure 4). This framework encourages DMNEs to use several mechanisms, a multi-strategy approach, to manage the complex and multifaceted nature of political risks in EMs. This upgraded analytical framework is a way to go for future empirical research on political risk management in EMs.

\subsection{Practical implications}

This research provides a number of practical implications. First, the presented holistic list of perceived political risks in EMs can assist managers in DMNEs in their considerations and choice of EMs to enter. Parsimonious identification of political risks is one of the most significant steps in outlining effective political risk management mechanisms. Second, a detailed illustration of the phases in the business project life cycle and the types of political risk that are likely to emerge in each phase serve as an assisting tool for the managers who make resource allocation decisions during IPOs and estimate ROIs. Third, although establishing high control over the business project in EMs has been the most preferred way to mitigate political risks, this study points to the significance of negotiation with the local project partners and building trust with them. Local partners not only assist DMNEs in political risk reduction, they also help in establishing understanding about the customers' preferences, requirements of local institutions, nuances of political influence and more importantly, gaining legitimate power from the local government. Still, such characteristics as reputation,
Political risk management

1137 
IMR

38,6 capabilities and strength of political connection with the host country governments should be carefully considered when choosing potential project partner in the EMs.

\section{Conclusions, limitations and further research directions}

This study investigates an under-developed yet fundamental question of how a DMNE perceives and manages political risks when undertaking infrastructure projects in EMs. Using an abduction-based qualitative research approach, we find that a DMNE identifies the political risks and decides the mechanisms to manage them at the commencement of "project preparation and development" stage of the project life cycle. We further find that some political risk factors are common in all EMs, but the overall nature of political risks in EMs is not same. We also find that political risks are subject to constraints from several mechanisms, where DMNE uses some mechanisms in all EMs to manage the political risks, but the use of some other mechanisms depend on the nature of political risks in each EM. Hence, our study develops a complete picture of the nature of political risks in EMs and its management from the DMNE's perspective.

Like all academic studies, our study has some limitations as well. Firstly, the empirical context is based on energy sector infrastructure IPOs undertaken by one Northern European MNE in five EMs. Due to this sample limitation, we explicitly acknowledge that our study's findings cannot be generalized to firms operating in other sectors or industries in EMs. Secondly, the study is also limited by the fact that case projects are only in five EMs. Future research might investigate whether the results of our study hold in other EMs. Thirdly, a limited number of case projects of the DMNE also raises questions on the study's generalizability even in a single sector of the energy business. We acknowledge these limitations and therefore view our study as exploratory. Large-scale follow-up studies should test the analytical framework developed in our study. Furthermore, we encourage researchers to cluster the political risk factors and explore the relationship between risks and specific mechanisms.

\section{References}

Ahmed, Z.U., Mohamad, O., Tan, B. and Johnson, J.P. (2002), "International risk perceptions and mode of entry: a case study of Malaysian multinational firms", Journal of Business Research, Vol. 55 No. 10 , pp. 805-813.

Ahuja, G. and Yayavaram, S. (2011), "Explaining influence rents: the case for an institutions-based view of strategy", Organization Science, Vol. 22 No. 6, pp. 1631-1652.

Ali, T. and Larimo, J. (2016), "Managing opportunism in international joint ventures: the role of structural and social mechanisms", Scandinavian Journal of Management, Vol. 32, pp. 86-96.

Blau, P.M. (1964), Exchange and Power in Social Life, John Wiley and Sons, New York, NY.

Buckley, P.J. (2000), Multinational Firms, Cooperation and Competition in the World Economy, Macmillan, London.

Butler, K. and Joaquin, D. (1998), "A note on political risk and the required return on foreign direct investment", Journal of International Business Studies, Vol. 29 No. 3, pp. 599-608.

Casson, M. and Lopes, T.D.S. (2013), "Foreign direct investment in high-risk environments: an historical perspective", Business History, Vol. 55 No. 3, pp. 375-404.

Cavusgil, S.T., Ghauri, P.N. and Akcal, A.A. (2013), Doing Business in Emerging Markets, Sage, London.

Chang, T., Hwang, B.G., Deng, X. and Zhao, X. (2018), "Identifying political risk management strategies in international construction projects", Advances in Civil Engineering, Vol. 2018, pp. 1-11. 
Chiao, Y.C., Lo, F.Y. and Yu, C.M. (2010), "Choosing between wholly-owned subsidiaries and joint ventures of MNCs from an emerging market", International Marketing Review, Vol. 27 No. 3, pp. 338-365.

Cova, B. and Holstius, K. (1993), "How to create competitive advantage in project business", Journal of Marketing Management, Vol. 9 No. 2, pp. 105-121.

Dandage, R., Mantha, S.S. and Rane, S.B. (2018), "Ranking the risk categories in international projects using the TOPSIS method", International Journal of Managing Projects in Business, Vol. 11 No. 2, pp. 317-331.

Deligonul, S.Z. (2020), "Multinational country risk: exposure to asset holding risk and operating risk in international business", Journal of World Business, Vol. 55 No. 2, 101041.

Deng, X., Low, S.P., Zhao, X. and Chang, T. (2018), "Identifying micro variables contributing to political risks in international construction projects", Engineering, Construction and Architectural Management, Vol. 25 No. 3, pp. 317-334.

Donthu, N., Kumar, S., Pattnaik, D. and Pandey, N. (2021), "A bibliometric review of international marketing review (IMR): past, present, and future", International Marketing Review. doi: 10. 1108/IMR-11-2020-0244.

Douglas, S.P. and Craig, C.S. (2011), "The role of context in assessing international marketing opportunities", International Marketing Review, Vol. 28 No. 2, pp. 150-162.

Dubois, A. and Gadde, L.E. (2002), "Systematic combining: an abductive approach to case research", Journal of Business Research, Vol. 55 No. 7, pp. 553-560.

Erramilli, M.K. and Rao, C.P. (1993), "Service firms' entry-mode choice: a modified transaction-cost analysis approach", Journal of Marketing, Vol. 57 No. 3, pp. 19-38.

Fletcher, M. and Plakoyiannaki, E. (2011), "Case selection in international business: key issues and common misconceptions", in Piekkari, R. and Welch, C. (Eds), Rethinking the Case Study in International Business and Management Research, Edward Elgar Publishing, Cheltenham, pp. 171-191.

Forlani, D., Parthasarathy, M. and Keaveney, S.M. (2008), "Managerial risk perceptions of international entry-mode strategies”, International Marketing Review, Vol. 25 No. 3, pp. 293-311.

Gao, C., Zuzul, T., Jones, G. and Khanna, T. (2017), "Overcoming institutional voids: a reputation-based view of long-run survival”, Strategic Management Journal, Vol. 38, pp. 2147-2167.

Gilpin, R. (2018), The Challenge of Global Capitalism: the World Economy in the 21st Century, Princeton University Press, Princeton, New Jerssey, NJ.

Han, X., Liu, X., Gao, L. and Ghauri, P. (2018), "Chinese multinational enterprises in Europe and Africa: how do they perceive political risk?", Management International Review, Vol. 58 No. 1, pp. 121-146.

Henisz, W.J. (2000), "The institutional environment for multinational investment", Journal of Law, Economics, and Organization, Vol. 16 No. 2, pp. 334-364.

Henisz, W.J. and Zelner, B.A. (2010), "The hidden risks in emerging markets", Harvard Business Review, Vol. 88 No. 4, pp. 88-95.

Hennart, J.F. and Slangen, A. (2015), "Yes, we really do need more entry mode studies! A commentary on Shaver", Journal of International Business Studies, Vol. 46 No. 1, pp. 114-122.

Hiatt, S.R. and Sine, W.D. (2014), "Clear and present danger: planning and new venture survival amid political and civil violence", Strategic Management Journal, Vol. 35, pp. 773-785.

Hsieh, L.H.Y., Rodrigues, S.B. and Child, J. (2010), "Risk perception and post-formation governance in international joint ventures in Taiwan: the perspective of the foreign partner", Journal of International Management, Vol. 16, pp. 288-303.

Huemer, L. (2004), "Activating trust: the redefinition of roles and relationships in an international construction project", International Marketing Review, Vol. 21 No. 2, pp. 187-201.

Ingram, P.L. and Silverman, B.S. (2002), The New Institutionalism in Strategic Management, Elsevier, Kidlington.
Political risk management 
IMR 38,6

ISO (2018), ISO 31000: Risk Management - Guidelines, the International Organization for Standardization, Geneva, available at: https:/www.iso.org/obp/ui/\#iso:std:iso:31000:ed-2:v1:en.

Jiang, W., Martek, I., Hosseini, M.R., Tamošaitienė, J. and Chen, C. (2019), "Foreign infrastructure investment in developing countries: a dynamic panel data model of political risk impacts", Technological and Economic Development of Economy, Vol. 25 No. 2, pp. 134-167.

Kardes, I., Ozturk, A., Cavusgil, S.T. and Cavusgil, E. (2013), "Managing global megaprojects: complexity and risk management”, International Business Review, Vol. 22 No. 6, pp. 905-917.

Khanna, T. and Palepu, K.G. (2010), Winning in Emerging Markets: A Road Map for Strategy and Execution, Harvard Business Review Press, Boston, Massachusetts, MA.

Khanna, T. and Rivkin, J. (2001), "Estimating the performance effects of business groups in emerging markets", Strategic Management Journal, Vol. 22 No. 1, pp. 45-74.

Khattab, A.A., Anchor, J. and Davies, E. (2007), "Managerial perceptions of political risk in international projects", International Journal of Project Management, Vol. 25 No. 7, pp. 734-743.

Knight, F.H. (1921), Risk, Uncertainty and Profit, Hart, Schaffner and Marx, New York, NY.

Kowalkowski, C., Windahl, C., Kindström, D. and Gebauer, H. (2015), "What service transition? Rethinking established assumptions about manufacturers' service-led growth strategies", Industrial Marketing Management, Vol. 45 No. 1, pp. 59-69.

Kraus, S., Ambos, T.C., Eggers, F. and Cesinger, B. (2015), "Distance and perceptions of risk in internationalization decisions", Journal of Business Research, Vol. 68 No. 7, pp. 1501-1505.

Langley, A. (1999), "Strategies for theorizing from process data", The Academy of Management Review, Vol. 24 No. 4, pp. 691-710.

Lessard, D.R. (1996), "Incorporating country risk in the valuation of offshore projects", Journal of Applied Corporate Finance, Vol. 9 No. 3, pp. 52-63.

Liesch, P.W., Welch, L.S. and Buckley, P.J. (2011), "Risk and uncertainty in internationalisation and international entrepreneurship studies", Management International Review, Vol. 51 No. 6, pp. 851-873.

Lopez-Duarte, C. and Vidal-Suarez, M.M. (2010), "External uncertainty and entry mode choice: cultural distance, political risk and language diversity", International Business Review, Vol. 19 No. 6, pp. 575-588.

Low, S.P., Liu, J.Y., Ng, S.H.M. and Liu, X. (2013), "Enterprise risk management and the performance of local contractors in Singapore", International Journal of Construction Management, Vol. 13 No. 2, pp. 27-41.

Luo, Y. (2001), "Towards a cooperative view of MNC-Host Government relations: building Blocks and Performance implications", Journal of International Business Studies, Vol. 32 No. 3, pp. 401-419.

Luo, Y. (2004), “A coopetition perspective of MNC-host government relations”, Journal of International Management, Vol. 10 No. 4, pp. 431-451.

Luostarinen, R. and Welch, L. (1990), International Business Operations, Kyriiri Oy, Helsinki.

Mabrouki, C., Bentaleb, F. and Mousrij, A. (2014), "A decision support methodology for risk management within a port terminal”, Safety Science, Vol. 63, pp. 124-132.

Marquis, C. and Raynard, M. (2015), "Institutional strategies in emerging markets", Academy of Management Annals, Vol. 9 No. 1, pp. 291-335.

Maxwell, J.A. (2013), Qualitative Research Design: an Interative Approach, SAGE, London.

McKinsey \& Company (2017), "Bridging infrastructure gaps: has the world made progress?", available at: https://www.mckinsey.com/industries/capital-projects-and-infrastructure/our-insights/ bridging-infrastructure-gaps-has-the-world-made-progress.

Melkonain, T. and Picq, T. (2011), "Building project capabilities in PBOs: lessons from the French special forces", International Journal of Project Management, Vol. 29 No. 4, pp. 455-467.

Meschi, P.X. (2005), "Environmental uncertainty and survival of international joint ventures: the case of political and economic risk in emerging countries", European Management Review, Vol. 2 No. 2, pp. 143-152. 
Miller, K.D. (1992), "A framework for integrated risk management in international business", Journal of International Business Studies, Vol. 23 No. 2, pp. 311-331, doi: 10.1057/palgrave.jibs. 8490270.

Miller, K.D. and Leiblein, M.J. (1996), "Corporate risk-return relations: returns variability versus downside risk", Academy of Management Journal, Vol. 39 No. 1, pp. 91-122.

Mullner, J. (2016), "From uncertainty to risk-a risk management framework for market entry", Journal of World Business, Vol. 51 No. 5, pp. 800-814.

Muthusamy, S.K., White, M.A. and Carr, A. (2007), "An examination of the role of social exchanges in alliance performance”, Journal of Management Issues, Vol. 19 No. 1, pp. 53-75.

Ngasri, N.E.M. and Freeman, S. (2018), "Conceptualizing network configurations as dynamic capabilities for emerging market born globals", International Studies of Management and Organization, Vol. 48 No. 2, pp. 221-237.

Nyamrunda, F.C. and Freeman, S. (2021), "Strategic agility, dynamic relational capability and trust among SMEs in transitional Economies", Journal of World Business, Vol. 56 No. 3, doi: 10.1016/j. jwb.2020.101175.

Oliveira, J.S., Yazdani, N., Cadogan, J.W., Hodgkinson, I.R., Tsougkou, E., Story, V.M. and Boso, N. (2018), "The empirical link between export entry mode diversity and export performance: a contingency-and institutional-based examination”, Journal of Business Research, Vol. 88, pp. 505-512.

Owusu, R.A., Sandhu, M. and Kock, S. (2007), "Project business: a distinct mode of internationalization”, International Marketing Review, Vol. 24 No. 6, pp. 695-714.

Oxford Economics (2017), Global Infrastructure Outlook, Oxford Economics, available at: https://www. oxfordeconomics.com/publication/open/283970.

PMI (2000), A Guide to the Project Management Body of Knowledge (PMBOK Guide), Project Management Institute, Pennsylvania, PA.

Puck, J.F., Holtbrugge, D. and Mohr, A.T. (2009), "Beyond entry mode choice: explaining the conversion of joint ventures into wholly owned subsidiaries in the People's Republic of China", Journal of International Business Studies, Vol. 40 No. 3, pp. 388-404.

Reimann, F., Ehrgott, M., Kaufmann, L. and Carter, C. (2012), "Local stakeholders and local legitimacy: MNEs' social strategies in emerging economies", Journal of International Management, Vol. 18 No. 1, pp. 1-17.

Richmond, H.J. (2002), "Learners' lives: a narrative analysis", The Qualitative Report, Vol. 7 No. 3, pp. 1-14.

Riessman, C.K. (2005), Narrative Analysis. in: Narrative, Memory and Everyday Life, University of Huddersfield, Huddersfield, available at: http://eprints.hud.ac.uk/id/eprint/4920/2/Chapter_1_-_ Catherine_Kohler_Riessman.pdf.

Sachs, T. (2006), Quantifying Qualitative Information on Risks (QQIR) in Structured Finance Transactions: Political Risk Quantification in PPP Infrastructure Projects, PhD Thesis, Nanyang Technological University, Singapore.

Samiee, S. and Chirapanda, S. (2019), "International marketing strategy in emerging-market exporting firms", Journal of International Marketing, Vol. 27 No. 1, pp. 20-37.

Samset, K. and Volden, G.H. (2016), "Front-end definition of projects: ten paradoxes and some reflections regarding project management and project governance", International Journal of Project Management, Vol. 34 No. 2, pp. 297-313.

Sawant, R.J. (2012), "Asset specificity and corporate political activity in regulated industries", Academy of Management Review, Vol. 37 No. 2, pp. 194-210.

Simangunsong, E.S., Hendry, L. and Stevenson, M. (2012), "Supply chain uncertainty: a review and theoretical foundation for future research", International Journal of Production Research, Vol. 50 No. 16, pp. 4493-4523, doi: 10.1080/00207543.2011.613864.
Political risk management 
IMR 38,6

Söderlund, J. and Tell, F. (2009), "The P-form organization and the dynamics of project competence: project epochs in Asea/ABB, 1950-2000", International Journal of Project Management, Vol. 27 No. 2, pp. 101-112.

Steffen, B. and Papakonstantinou, V. (2015), Mitigation of Political and Regulatory Risk in Infrastructure Projects, World Economic Forum Publications, Geneva.

Stosberg, J. (2005), Political Risk and the Institutional Environment for Foreign Direct Investment in Latin America, Peter Lang, Frankfurt.

Streatfield, P.J. (2001), The Paradox of Control in Organizations, Routledge, London.

Teagarden, M.B., Glinow, M.A. and Mellahi, K. (2018), "Contextualizing international business research: enhancing rigor and relevance”, Journal of World Business, Vol. 53 No. 3, pp. 303-306.

Turner, J.R. (2001), "Project contract management and a theory of organization", International Journal of Project Management, Vol. 19 No. 8, pp. 457-464.

Turner, J.R. (2009), The Handbook of Project-Based Management: Leading Strategic Change in Organization, McGraw-Hill, New York, NY.

Vissak, T., Francioni, B. and Freeman, S. (2020), "Foreign market entries, exits and re-entries: the role of knowledge, network relationships and decision-making logic", International Business Review, Vol. 29 No. 1, doi: 10.1016/j.ibusrev.2019.101592.

Voelker, C., Permana, A., Sachs, T. and Tiong, R. (2008), "Political risk perception in Indonesian power projects", Journal of Financial Management of Property and Construction, Vol. 13 No. 1, pp. 18-34.

Watson IV, G.F., Weaven, S., Perkins, H., Sardana, D. and Palmatier, R.W. (2018), "International market entry strategies: relational, digital, and hybrid approaches", Journal of International Marketing, Vol. 26 No. 1, pp. 30-60.

Welch, L.S., Benito, G.R.G. and Petersen, B. (2018), Foreign Operation Methods: Theory, Analysis, Strategy, Edward Elgar, Cheltenham.

Yin, R.K. (2003), Case Study Research: Design and Methods, Sage Publications, Thosand Oaks, California, CA.

Zhang, J. and Wei, W.X. (2012), "Managing political risks of Chinese contractual projects in Libya", Project Management Journal, Vol. 43 No. 4, pp. 42-51.

\section{Corresponding author}

Ahmad Arslan can be contacted at: ahmad.arslan@oulu.fi

For instructions on how to order reprints of this article, please visit our website:

www.emeraldgrouppublishing.com/licensing/reprints.htm

Or contact us for further details: permissions@emeraldinsight.com 